\title{
Antecedents of Customer Purchase Intention
}

\author{
Sanjeev Pandey ${ }^{1}$, Dr. Sandeep Srivastava ${ }^{2}$ \\ ${ }^{1,2}$ Jaypee University of Engineering and Technology, Guna, M.P.
}

\begin{abstract}
Customer purchase intention serves as an early indication of the sales of the final products. The organizations try to uncover the customer purchase intention. Customer purchase intention consists of an amalgamation of various antecedents that build it up. The literature related to the antecedents of customer purchase intention is scattered and a properly organized and comprehensive study has not been done that highlights the relations between these antecedents and the customer purchase intention. In this paper, a comprehensive study is done related to the antecedents of the customer purchase intention. The research papers are arranged in the chronological order and they are analyzed based on various parameters.An attempt has been made to do the meta-analysis based on the subjective scores given to these antecedents. The result of the meta-analysis highlights the segregation of the antecedents based on consensus and non-consensus. The results of this paper are very useful to the organizations that are indulged in understanding customer purchase intention and might also serve as a base study to the researcher studying customer purchase intention. In the scenario of cut-throat competition an organization's goal is to earn profit. To achieve this goal, it is important to understand the customer behavior deeply. In the present paper an analysis has been done onone hundredpapersthat are published in different renowned journals related to customer purchase intention. It is found that there are various antecedents that are responsible for customer to purchase a particular product. Definitions of the different antecedents which directly affect customer purchase intention are also presented. The antecedents are classified in two different categories namely i) factors of consensus and ii) factors of nonconsensus.
\end{abstract}

Keywords: Purchase Intention, Customer, Brand, Price, trust,

\section{Introduction}

Understanding the customer purchase behavior is vital for any organization. In the present business scenario, it is even more important as the customer brand loyalty is changing very fast and the customer switching behavior is increasing rapidly. Hence, it is imperative for an organization to find out the factors that influence customer purchase intention. In this paper, an exhaustive analysis is being done on one hundred relevant research paper published in the renowned journals. The customer is defined as an individual who purchases a particular product, whereas a consumer is a person who consumes or uses that product. Purchase intention means attempting to buy a product. (Dodd Monroe, 1991).Purchase intention is the implied promises to one's self to buy the product again whenever one makes next trip to a market. (Fandos \& Flavian, 2006). Purchase intention means the likelihood that a consumer will buy a particular product; the higher the purchase intention, the greater the purchase probability. (Kotler, 1991)

\section{Literature Findings}

It is desirable for any organization to know the customer purchase intention. Many researchers are continuously trying to design a model which can depict the customer purchase behavior.A lot of research is going on in this area. In the present paper, an exhaustive study has been done on one hundred papers that are published in different renowned journals.Purchase Intention (Black's Law Dictionary)is termed as the plan in which a person intends to buy particular goods or service sometime in the near future. The plan is to buy an item but the timing is left to the individual to plan. The antecedents which are considered commonly by many authors are factors of consensus whereas factors which are considered by some author but not considered by others are factors of non-consensus.

Antecedents of CPI: - A suitable way to present the CPI (Customer Purchase Intention) concepts is to logically group them into "antecedents". Table 1 describes the counts of antecedents as appeared in the literature review with proper references. Table 1 highlight that among all the important antecedents that has been considered in 100 papers, Attitude has maximum numbers of total counts [29], therefore in any purchase done by the customer, attitude can be the strongest antecedents followed by the price [20], Subjective Norms [14], Brand Image [13], Trust [12] and so on. There are various independent variables which are considered only in few studies or papers. These factors are categorized as Others Counts [26]. 
Table 1: Counts of Antecedents of CPI

\begin{tabular}{|l|l|l|l|}
\hline S. No. & Antecedents of CPI & References & Total Counts \\
\hline 1$)$ & Brand Image & {$[1,3,4,14,20,22,41,48,56,57,60,62,88,33,33]$} & {$[13]$} \\
\hline 2$)$ & Price & {$[2,3,10,19,20,22,23,31,34,35,38,40,48,53,60,63,66,7$} & {$[20]$} \\
& & $8,84,98]$ & {$[12]$} \\
\hline 3$)$ & Trust & {$[5,9,12,18,27,28,30,33,66,79,81,84]$} & {$[29]$} \\
\hline 4$)$ & Attitude & {$[6,11,17,18,19,26,29,30,31,44,46,50,56,57,59,59,63$,} & \\
& & $67,68,70,72,74,75,90,93,94,95,96,97,100]$ & \\
\hline 5$)$ & Perceived Quality & {$[15,32,35,53,55,59,60,62,89]$} & {$[9]$} \\
\hline 6$)$ & Perceived Value & {$[5,9,15,30,38,40,47,59,76,78,83]$} & {$[11]$} \\
\hline 7$)$ & Demographic & {$[19,20,42,43,51,52,66,74,93]$} & {$[9]$} \\
\hline 8$)$ & Normative Beliefs \&self Efficacy & {$[18,62,72]$} & {$[3]$} \\
\hline 9$)$ & Promotion & {$[20,35,38,53,59,64,76]$} & {$[7]$} \\
\hline 10$))$ & Country of Origin (COO) & {$[2,24,25,57,86,88]$} & {$[6]$} \\
\hline 11$)$ & Health Consciousness & {$[19,20,77,78,83]$} & {$[5]$} \\
\hline 12$)$ & Customer Satisfaction & {$[15,71]$} & {$[2]$} \\
\hline 13$)$ & Convenience & {$[10,12,13,20,48]$} & {$[5]$} \\
\hline 14$)$ & Motivation & {$[20]$} & {$[1]$} \\
\hline 15$)$ & Subjective Norms & {$[6,11,18,19,57,63,65,67,74,75,81,90,97,100]$} & {$[14]$} \\
\hline 16$)$ & Perceived behavioral control & {$[6,11,19,29,57,63,65,74,75,90,97]$} & {$[11]$} \\
\hline 17$)$ & Others & {$[7,8,21,32,36,37,39,45,49,51,52,54,58,61,62,69,71$,} & {$[26]$} \\
& & $73,80,82,85,87,89,91,92,99]$ & {$[183]$} \\
\hline
\end{tabular}

Note: While 100 articles were reviewed, some articles involved more than one constructs and were, therefore, placed in multiple categories.

Antecedents which affect CPI cannot be measured directly. In literature it is found that some researchers have focused on single or less number of antecedents while other researchers have used collection of large number of antecedents. From the study of various CPI based papers, it has been decided to form a consolidated and reasonable list which consists of almost all the antecedents which have been focused in literature for different applications. The final list comprised of 17 antecedents which have discussed in the previous section. These 17 antecedents have been categorized into two broad categories: Consensus and Nonconsensus. We have classified almost 100 research papers with respect to these antecedents and their counts are given in above table.

\subsection{Factors of consensus}

1) Brand image:The brand image is an important aspect towards purchase intention. It guides the consumers to consume more on the specific brand having a good brand image. Further, it helps consumers in taking a call on an important decision - that of ascertaining which brand is a more suitable option for them; also it induces the consumers to make purchase intentions. As per Keller $(1993 ; 1998)$, a brand image is a manifestation of the perceptions - as brand associations - deeply ensconced in the consumers' memory. Kotler (2000) has a more generic definition for the brand in that he claims a brand to be a holistic whole resulting from the intertwining of attributes like name, symbol, design, or a combination of these; the idea being to distinguish one's products and services from those of the competitors. Brand name is the most important attributed considered by teenagers. In the words of Richardson et al. (1994), brand image is an agglomeration of attributes and associations; those with which consumers find a brand connect. Putting a bit differently, Bullmore (1984) comes up with a view which emphasizes that brand image oozes out of the thoughts and feelings of the consumers about the brand. White's (2003) take on brand image is that of a complete and succinct picture of the brand held by those who are aware about it.

2) Price:Kotler \& Keller (2006) earmarks price as a key factor in stirring up the purchase intentions of the consumers. They opine that price consciousness goes a long way in establishing the purchase intention credentials. Broekhuizen and Alsem (2002) argue that customers would go on to pay even a premium for customized products because they view it as a better way for need fulfilment. Wind and Rangaswamy (2001) harp that price takes a backseat in a scenario when a company enables the co-production process and thereby tailoring the products as per the needs, which subsequently lends value to the product. A reasonable price and a good general outlook of the products is a reason enough to trigger a high level satisfaction and confidence for the consumers to purchase the product. In simple terms, price is the amount of money customers shell out in order to get a product.( Kotler, 2004). Having an utmost bearing on the profitability quotient of the company concerned, the price comes along as a significant variable in the scheme of things. There exists a thorough distinction between the price and the price deals. Some researchers like Aaker (1991) have gone on to the extent saying that there exists a negative effect of price deals on consumer's behavioural intentions. Though price deals 
entices the customers in a retail store, it results in a trade-off between quality and internal reference price of the brand, thus leading to perceptions about low quality. This eventually is in stark contrast with the motive of price deals.

3) Perceived quality:Ultimately it boils down to the customers' perception about total excellence and superiority of the product and not the actual quality of the product per se (Zeithaml, 1988; Aaker, 1991). Olsen (2002) maintains that there is a strong relationship between consumers' perceived quality, satisfaction, loyalty and buying intention for foodstuffs. Lang and Crown (1993) stated that aspects like price, aesthetics and quality are important considerations when buying decision for clothing is made. Bernues et al. (2003) hold the view that the intrinsic attributes of the product are aspects such as flavour, colour, shape and appearance; extrinsic attributes comprise of non-physical features such as brand quality certificate, price, country or place of origin, packaging, product information, and the shop where it is displayed or eventually sold from.

4) Demographic:Based on a previous study by Park et al., (2008), this research will only focus on the demographic variables of age, income and purchasing frequency. Age differences were examined in various studies (Schmitt, 1997; Landry, 1998; Anderson and He, 1998). The findings of these studies indicated that younger consumers were more influenced by fashion; more drawn to famous foreign brands and were less sensitive to higher prices.

Of utmost significance are features such as age, gender and race (demographic) which have a bearing on the purchase intentions. The striking point is that consumers in different age groups have different choice behaviours. A nineteen year old may have a very contrasting buying appetite than a twenty-five year old. For example, some young consumers are more concerned on the labeled products than other young consumers (Nabil \&Imed, 2010). The effect of gender depends on some factors. For example, females are more concerned about those kinds of products that are directly related to house because as housewives, the products quality is far more captivating for them. As such their buying drive is more inclined towards the label, brands and quality (Ahasanul; Ali \&Sabbir, 2006; Safiek, 2009b).

5) Perceived value:In the assessment of Zeithaml (1988) perceived value is defined as the utility a product brings to the consumer basis the perception of what is received (e.g. quality, satisfaction) for what is shelled out ( e.g. price, nonmonetary costs).Monroe and Dodds (1985) directly related perceived value to preferences or choice, whereby the larger the perceived value is, the more likely the consumer will express a willingness to buy or have a preference for the product. Perceived value has is the most important indicator to forecast purchase intentions and has been viewed is an important measures for gaining a competitive advantage (Zeithaml, 1988; Dodds et al., 1991; Cronin et al( 2000).

Explicitly reflected through the literature review are four values which one associates with the purchase of virtual goods. The first in the line is the enjoyment value which increases the fun quotient one attaches with playing a game. The second is the character competency value which augments character strength and power in the game scenario. It explores the real character concealed inside. The third value is the visual authority value that emanates from the purchase of game items by gamers to fit into the beautification of their status in the social perspective of the game. The fourth and the last is the monetary value which rakes in the visual currency function for the game users and are, moreover cost effective and reasonably priced.

6) Trust:Trust is defined as the trustee's appropriate performance to fulfill the trust or satisfaction. Mayer et al. (1995) also defined trust as a behavior of one person based on his/her beliefs about the characteristics of another person. Based on this definition, it is composed of three dimensions to represent the perceived trustworthiness of the trustee are ability, benevolence, and integrity (Gefen et al., 2003). In other words, if the trust or perceives a vendor's competence (ability), fairness (benevolence), and ethics (integrity) to be sufficient; consumers will develop the intention to purchase toward trustee. For example, trust illustrates the belief and expectation of consumers in the quality of manufacture, delivery, and warranty from the vendor. In essence, we can expect that an increase in trust will directly and positively have a bearing on the purchase intention.

7) Attitude:In order of influence, Attitude towards purchasing customized PC, followed by self-confidence, and subjective norm, have an influence on behavioral intention. Perceived knowledge has a resounding effect of self-confidence and attitude; subjective norm and perceived usefulness affects attitude in a positive way. In contrast a direct effect of perceived knowledge on behavioral intention is effectively ruled out. According to (Bagozzi\&Dholakia, 2002) the world wide used definition of attitude conceptualizes of it's an assessment such 
as spiritual predisposition that is communicated by assessing a specific object with some degree of positive or negative.

8) Normative belief and Self efficacy:Ajzen (1991) stresses that the theory of planned behaviour emphasises to put the constructs of self-efficacy belief or perceived behavioural control within a more generic framework of the relations among beliefs, attitude, intentions and behaviours. As per Badura (1986) Self-efficacy is closely related to beliefs and behaviours. Davis (1989) comes up with the ideation that self-efficacy also impacts decisions of computer usage and adoption. Extending further, it is explained that individuals who consider internet as too technical and complex and believe that they will never be able to size-up the internet technology, will prefer avoiding them and are less likely to use them. Gist (1989) posits that self-efficacy is an important motivational variable which has a distinct bearing on individual effect, persistence of efforts and motivation.

According to Bandura (1986), self-efficacy describes the confidence that individuals express in their ability to purchase Home-use BPM, not environmental or external obstacles. Since PBC had a positive influence in consumer purchase intention and self-efficacy is underlying dimension of PBC, so we can assume that there was a correlation between self-efficacy and intention to purchase Home-use BPM.

9) Country of origin: The COO concept evolved into a more complex notion as global production operations became increasingly diverse and new market opportunities emerged. Initially, the notion of the COO was perceived as analogous to the "made-in" country, Dichter (1962), (Nebenzahl et al., 1997). The large body of existing research has recognized the importance of Country of Origin (COO) effects on consumers ${ }^{\text {ee }}$ product evaluations and purchasing decisions, Bilkey and Nes (1982), Al-Sulaiti and Baker(1998). Mourali (2005) found that consumers rely more on the $\mathrm{COO}$ cue when the product origin facets are perceived as congruent. Higher perceived product origin congruency increases the perceived reliability of the COO image held by consumers. The concept of COO involves the country where the brand originates or is manufactured (Ha-Brookshire and Yoon, 2012). Country of origin or the "made in" label is one of the essential evaluation criteria in the purchasing decision (Supanvanij and Amine, 2000; Abedniya and Zaeim, 2011 Many alternatives are for customer to purchase certain products as there are already many aspects that have an influence on choice of brand.

10) Health consciousness: The most frequent purpose to purchase organic food is due to consumer's perception that organic food is healthy, Davies et al (1995). Also, health consciousness is known to predict attitudes, intention and purchase of organic food. Fotopoulus and krystallis (2002) have their own opinion on health consciousness that reflects the impact in purchase intention of organic food. Instrumental in influencing consumption choice, enhanced healthcare via proper nutrition has grabbed much attention. Health consciousness best describes those "consumers who are aware and concerned about their state of wellbeing and are motivated to not only enhance and / or maintain their health and quality of life, but also safeguarding against ill-health through engagement in health behaviours and remaining health conscious. A plethora of studies coming out in recent years have shed insights on potential health benefits (or risks as well) linked with coffee consumption; the results are contentious in that they remain inconclusive at large. Whilst coffee is reported to increase cardiovascular risk factors like high blood pressure, a slew of suggest contradictorily suggests coffee to have a protective effect on the heart and reduced risk of stroke. Some other studies have highlighted the protectiveness coffee imparts to health ranging from type 2 diabetes to Parkinson's disease, to liver disorders to obesity.

\subsection{Factors of non-consensus}

1) Promotion and Advertisement:Purchase Intention is simply the extent to which consumers would go as far as the buying activity of a product or service is concerned. Normally what consumers do is that they make a thorough comparison about the differences amongst the alternative offerings and competitor promos- like redemption, discount, distribution or premium - including the location and condition of the purchased product (Zeithaml et al., 1985). Leveraging Advertising for product promotion is an immensely popular marketing strategy. It is the reach per se of advertising that makes it a viable option with TV, newspaper, magazine, or direct mail advertisements impacting our daily lives. The central idea behind advertising is to make use of the endorsers' fame to endorse a product and make consumers churn out reliability of the product. The researchers also found that the authenticity of advertising spokespersons / endorsers is one of the driving factors influencing purchase intentions, and the extent to which it goes up, the higher will be the brand attitudes and positive advertising (Laffery\& Goldsmith, 1999). If the spokespersons showcase a positive attitude about the advertised product, it will translate into an overwhelming response of the consumers and will subsequently lead to consumers' connect of the product with the spokespersons (Chen \& Chang, 2001).

2) Convenience:Convenience stores (c-stores) constitute a successful format in developed markets such as the U.S., Canada, Europe, and Japan. As an example, 7-Eleven became the largest worldwide convenience store 
chain in March 2007, operating 34000 stores in 17 countries, even larger than the worldwide number of McDonald's stores (Planet Retail, 2007). Large multinational retailers are also opening convenience store formats in different markets. Only a few studies of convenience stores (c-stores) are found in the literature and they have all been held in a developed market context. In addition to a convenient location, other convenience incentives offered by retailers, such as longer operating hours or ample parking, can draw patrons to a store (Hansen and Deutscher, 1977).

3)Motivation:Consumer motivations are triggered by the many stimuli surrounding us in everyday life. We can find out consumer motivation through many factors surrounding us in daily life. These can be a myriad of triggers viz. ads in the grocery store, the speech of others, unconscious emotions, conscious feelings, colours, shapes, and news received (Simonson, 2005). The aforesaid motivations can be conscious as well as unconscious and is mainly affected by being ensconced in the cultural diversities of countries (Usunier et al, 2009). Since long, many big studies have worked around the idea of exploring thoughtful consideration or adjudication with regards to conscious decision making. A case in point is the gambling theories. (Bargh, 2002). Today, novel works in the ambit of consumer neuroscience, have unearthed thee importance of gauging unconscious motivation factors as they are omnipresent in lives of consumers. Consumers in the real world have many other needs and goals to be met than conscious processing of advertising and product specific information.

4) Consumer satisfaction: High up the pecking order, customer satisfaction commands a central place in the ideation of consumer behaviour. The reasons for this are not far : it is defined as customers' feelings for a certain value of the product or service, resulting out of the usage of a specific entity's proposition in precise use situations that is absolutely necessary ( Woodruff, 1993). According to Olsen (2002) there exists a strong relationship between consumers' perceived quality, satisfaction, loyalty and buying intention of food items. Yearning for achieving customer satisfaction, companies must be competent enough to build and maintain lasting associations with the customers through a virtuous cycle of satisfaction of varied needs and demands, and subsequently customer loyalty with the company by doing business on an on-going basis (La Barbera, \& Mazursky, 1983).

5) Safety concern:Henson (1996) opines that customers are more than willing to shell out for a value attached with improvements of food safety. The author elaborates further that young consumers and females are most willing to pay for a decrease in risk of food poisoning. The author pinpoints the factors, which have a bearing on the willingness to pay for decrease in risk of food poisoning, as: self-experiences of food poisoning, their respective attitudes towards food poisoning, perceived control over risk of food poisoning and finally the customers' distinguishing characteristics. Many authors (Padel and Foster, 2005; Schifferstein\& Oude Ophuis, 1998) have posited food safety as a precursory motive for buying organic food. That said food safety's relationship with attitudes and intentions towards organic foods is still to be put into a model, formally though. Adding to the intrigue, Angulo et al. (2003) found that Spanish customers were duly worried over issues of food safety.

6) Customer loyalty:It is an important concept for both academics and marketers. The former develop theoretical frameworks about the antecedents, components, behavioral consequences and, in general, the psychological dynamics of customer loyalty. The latter intend to develop quality relationships with customers and hence increase business and customer retention. The interest in the loyalty topic is due to the firm belief inthe profitability of loyal customers (Gupta et al. 2004; Reichheldet al. 2000). The most commonly used theoretical framework to predict customer behavior in repeat buying contexts is the satisfaction-profit chain (Anderson and Mittal 2000; Dick and Basu 1994): loyalty is built up of attitudinal loyalty (consisting of commitment, trust, and satisfaction, also called perceived relationship quality), which leads to repeat patronage intentions, which in turn lead to loyal behavior and, finally, to more profits (Reinartzand Kumar 2000).

7) Perceived usefulness \& Ease of use:In yet another fascinating study, Davis (1989) presented an interesting fact: that of finding the relative strength of the usefulness to usage relationship, compared with, the ease of use to usage relationship. It was found that usefulness by all means was strongly related to usage than was the ease of the use. Another compelling study by Chin and Todd (1995) revealed that was no empirical support or grounding reason for the split of significant constructs into two dimensions ( read usefulness and effectiveness). Perceived Usefulness is the willingness of a person to transact with a particular system. The Technology Acceptance Model (TAM) describes Perceived Usefulness as a measure of how a person would think about using a particular system and how it would sustain his/her job. In an organization, people perform better to get raises, promotions, bonuses, and other rewards. A study by Tan and Teo (2000) shows that Perceived 
Usefulness is one of the main factors in terms of adaptation of innovations (how people adjust to a change).Perceived Usefulness is the willingness of a person to transact with a particular system. The Technology Acceptance Model (TAM) describes Perceived Usefulness as a measure of how a person would think about using a particular system and how it would enhance his/her job. In an organization, people perform better to get raises, promotions, bonuses, and other rewards. A study by Tan and Teo (2000) shows that Perceived Usefulness is one of the major factors in terms of adaptation of innovations (how people adjust to a change).

Analysis of papers: A total of 300 research papers were downloaded related to the customer purchase intention out of them a thorough study of 100 papers have been done. The papers which are published in renowned Journals between 2009 to 2016 have been analyzed and arranged in chronological order to understand Independent variables which affect customer purchase intention.

Table 2 is drawn which contains the details of paper along with the Sampling Techniques, factors affecting customer purchase intention and limitations as suggested by the researchers. Authors in those papers have used variety of samples and method/techniques to do analysis and have mentioned various variables. Authors also have mentioned various limitations which are properly tabulated in Table 2.

Table 2: Description of Papers in Chronological Order

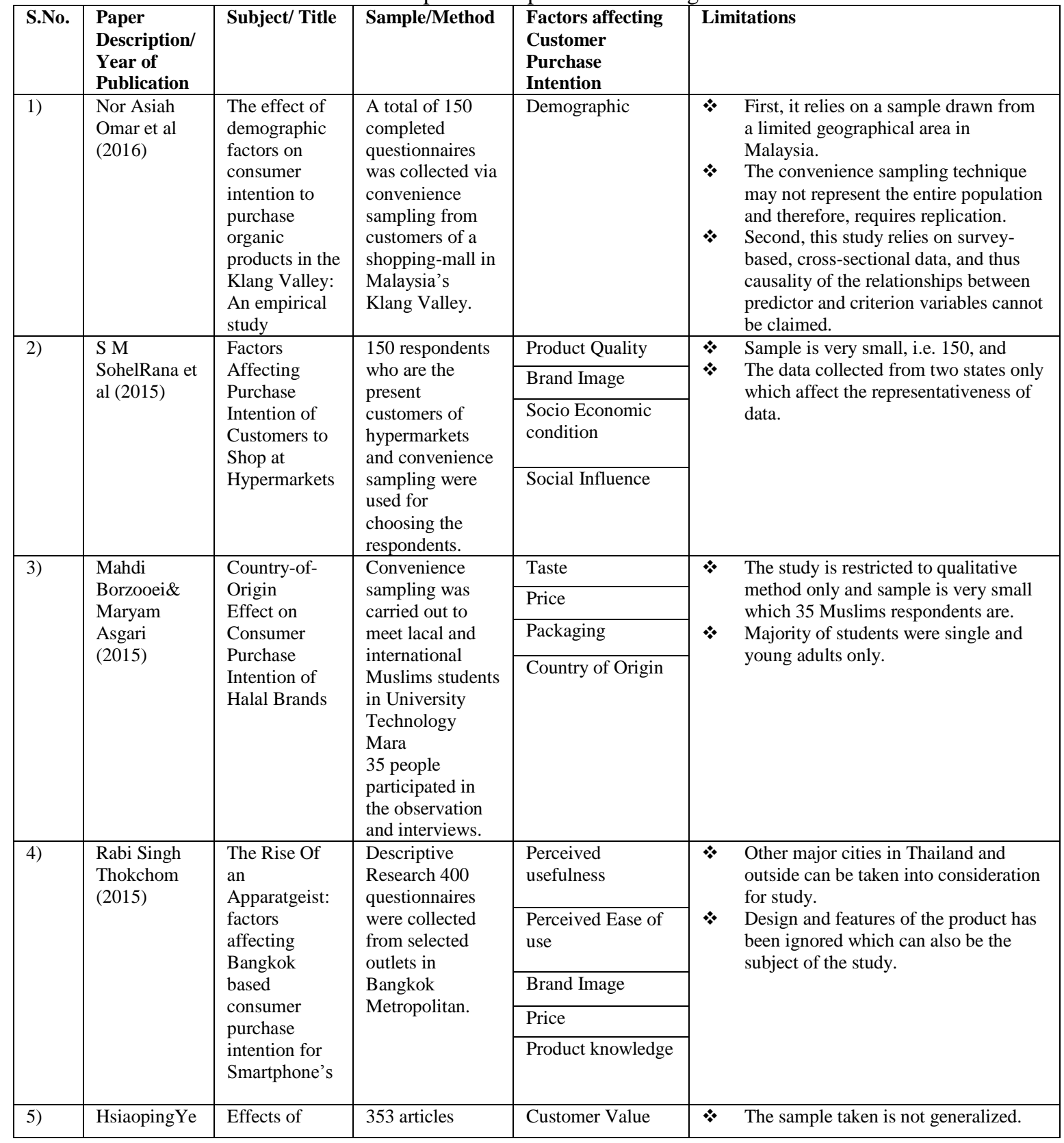




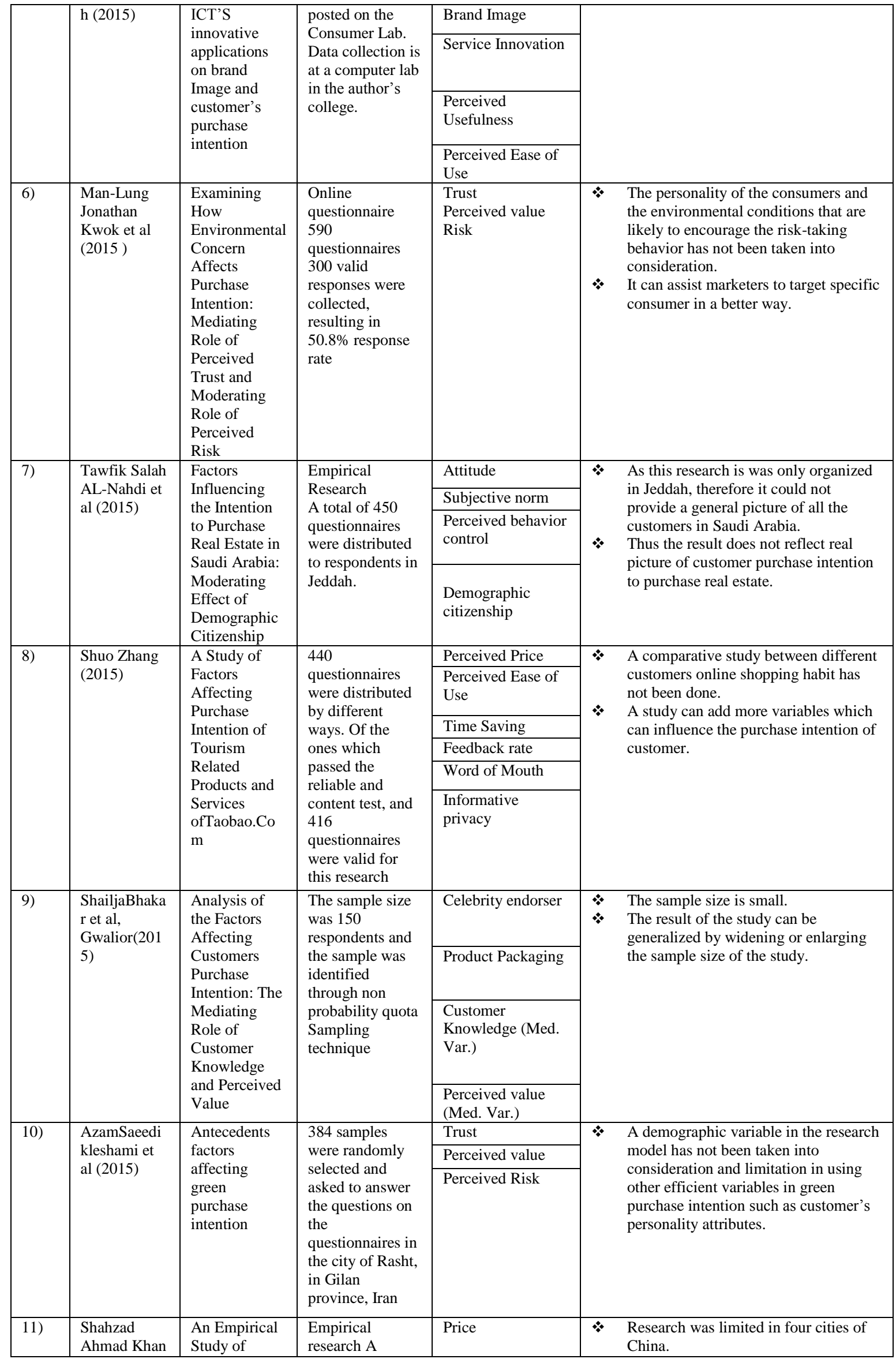




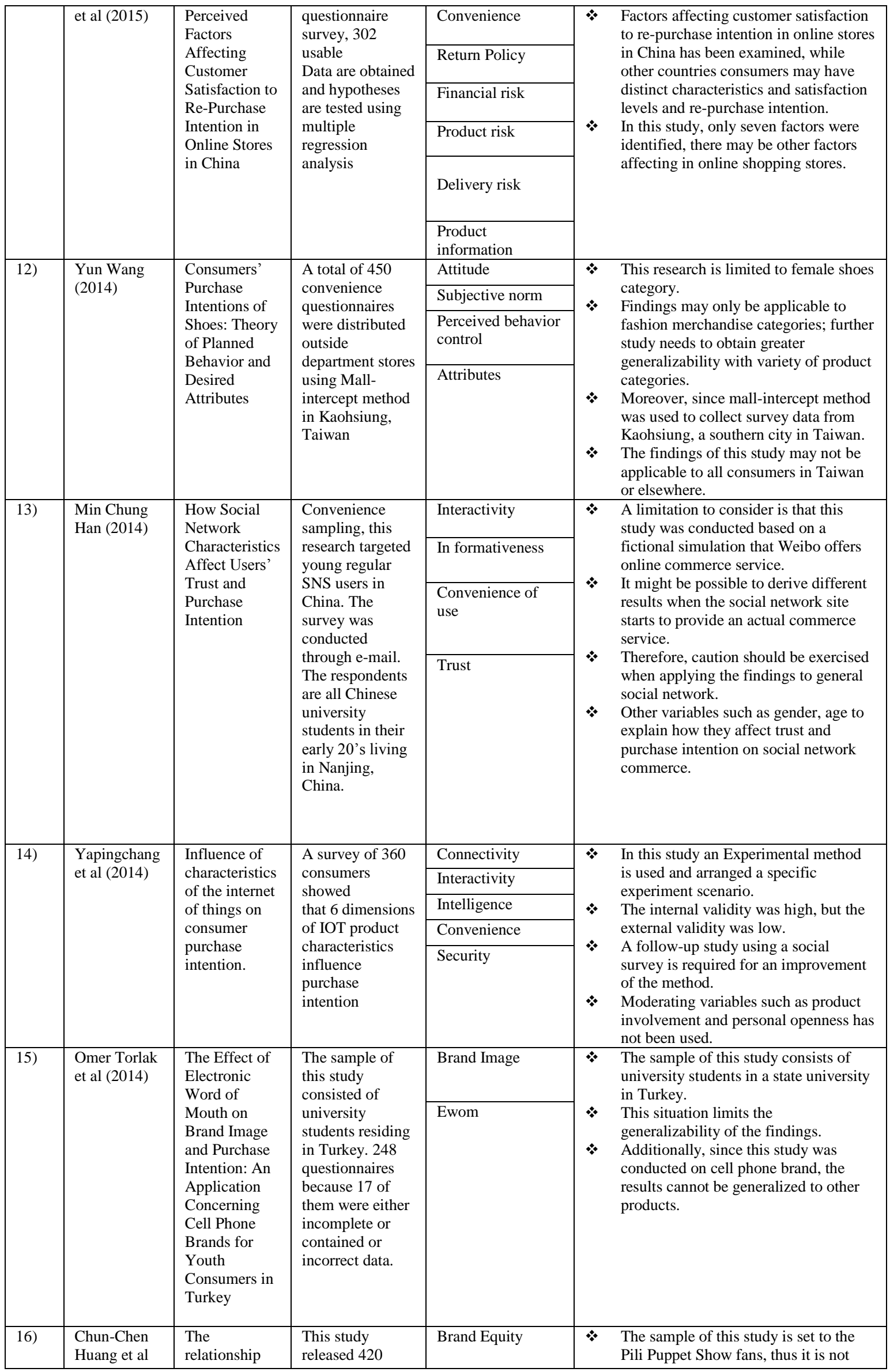




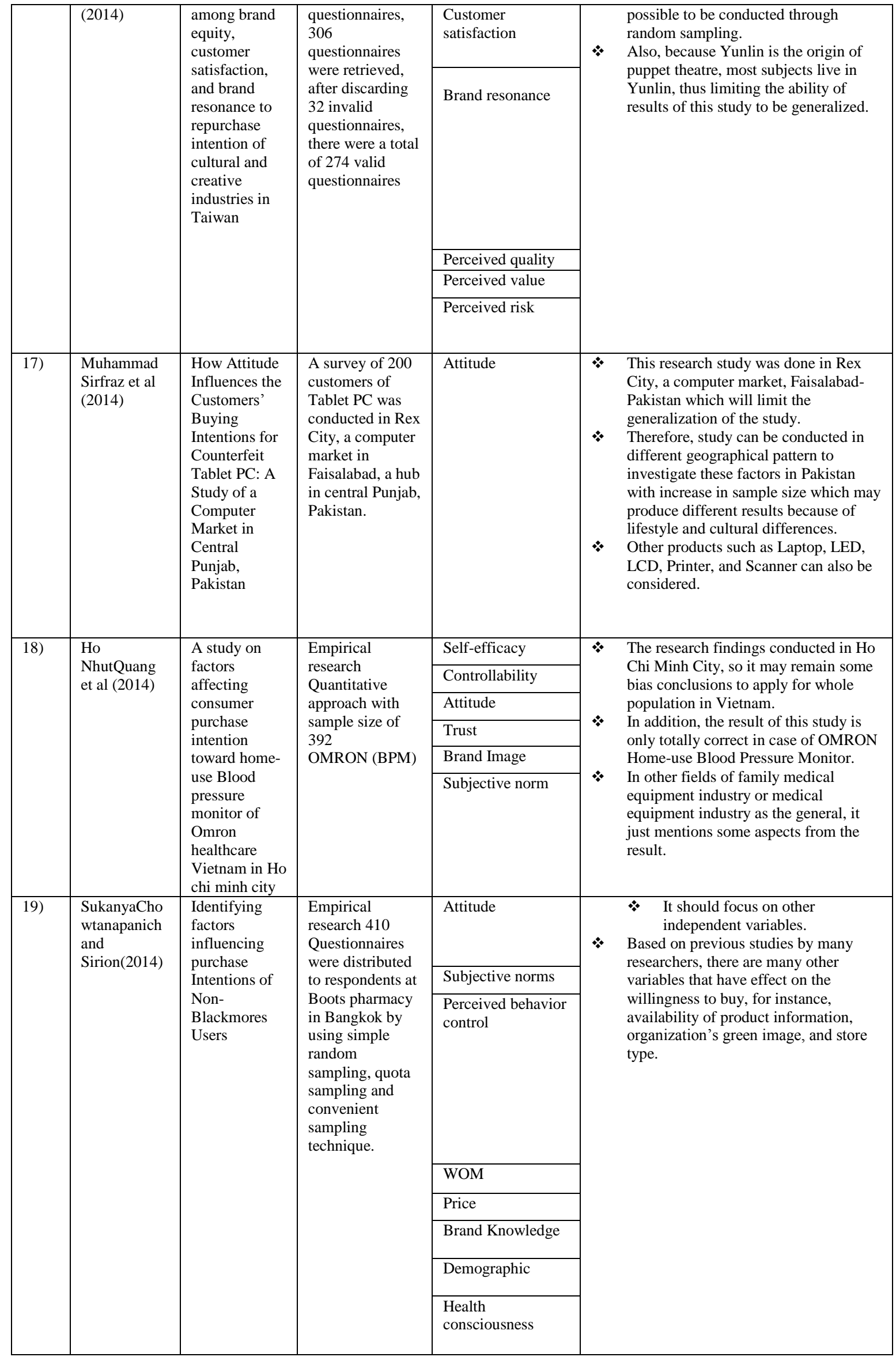




\begin{tabular}{|c|c|c|c|c|c|c|}
\hline \multirow[t]{10}{*}{ 20) } & \multirow[t]{10}{*}{$\begin{array}{l}\text { Ying-Fang } \\
\text { Huang \& } \\
\text { Hoang Sa } \\
\text { Dang (2014) }\end{array}$} & \multirow{10}{*}{$\begin{array}{l}\text { An Empirical } \\
\text { Analysis on } \\
\text { Purchase } \\
\text { Intention on } \\
\text { Coffee } \\
\text { Beverage in } \\
\text { Taiwan }\end{array}$} & \multirow{10}{*}{$\begin{array}{l}\text { Empirical } \\
\text { Research } \\
260 \text { respondents } \\
\text { were analyzed by } \\
\text { exploratory } \\
\text { factor }\end{array}$} & Product Image & \multirow[t]{10}{*}{$\%$} & \multirow{10}{*}{$\begin{array}{l}\text { The sample population only included } \\
\text { customers in Kaohsiung; therefore, it } \\
\text { may not be suitable to apply the } \\
\text { research results presented therein to } \\
\text { other parts of Taiwan. } \\
\text { Different cities have different types of } \\
\text { customers and different economic } \\
\text { levels. } \\
\text { The empirical data for this study are } \\
\text { only collected through the } \\
\text { questionnaire method. Qualitative } \\
\text { research can also be considered. }\end{array}$} \\
\hline & & & & Product Attributes & & \\
\hline & & & & Brand & & \\
\hline & & & & $\begin{array}{l}\text { Atmosphere and } \\
\text { Environment }\end{array}$ & & \\
\hline & & & & Taste & & \\
\hline & & & & Healthy benefits & & \\
\hline & & & & Motivation & & \\
\hline & & & & $\begin{array}{l}\text { Promotion \& } \\
\text { Advertising }\end{array}$ & & \\
\hline & & & & Convenience & & \\
\hline & & & & Demographic & & \\
\hline \multirow[t]{4}{*}{ 21) } & \multirow{4}{*}{$\begin{array}{l}\text { RizwanRahe } \\
\text { em Ahmed et } \\
\text { al } \\
(2014)\end{array}$} & \multirow{4}{*}{$\begin{array}{l}\text { Impact of } \\
\text { Product } \\
\text { Packaging on } \\
\text { Consumer's } \\
\text { Buying } \\
\text { Behavior }\end{array}$} & \multirow{4}{*}{$\begin{array}{l}\text { Empirical } \\
\text { research } \\
\text { Primary research } \\
150 \text { respondent } \\
\text { SPSS software } \\
\text { used }\end{array}$} & Packaging color & \multirow[t]{3}{*}{$\%$} & \multirow{4}{*}{$\begin{array}{l}\text { One should not consider the packaging, } \\
\text { the solely factor for the success of any } \\
\text { product. } \\
\text { Therefore, one should also take up } \\
\text { other important factors of the } \\
\text { marketing while they are launching } \\
\text { new products or revitalize old products. }\end{array}$} \\
\hline & & & & Packaging Material & & \\
\hline & & & & Design Wrapper & & \\
\hline & & & & Innovation & & \\
\hline \multirow[t]{5}{*}{ 22) } & \multirow{5}{*}{$\begin{array}{l}\text { Muhammad } \\
\text { Arslan\& } \\
\text { Rashid } \\
\text { Zaman } \\
\text { (2014) }\end{array}$} & \multirow{5}{*}{$\begin{array}{l}\text { Impact of } \\
\text { Brand Image } \\
\text { and Service } \\
\text { Quality on } \\
\text { Consumer } \\
\text { Purchase } \\
\text { Intention: A } \\
\text { Study of } \\
\text { Retail Store in } \\
\text { Pakistan }\end{array}$} & \multirow{5}{*}{$\begin{array}{l}\text { Empirical } \\
\text { research } \\
\text { Sample of } 301 \\
\text { consumers of } \\
\text { large retail stores } \\
\text { residing in } \\
\text { Lahore and } \\
\text { Islamabad of } \\
\text { Pakistan. Data } \\
\text { were collected } \\
\text { for quantitative } \\
\text { research. }\end{array}$} & Price & \multirow{5}{*}{$\%$} & \multirow{5}{*}{$\begin{array}{l}\text { The research was unable to prove a } \\
\text { significant relationship of price. } \\
\text { Research can be conducted on the } \\
\text { importance of store environment, } \\
\text { which can generate satisfaction and } \\
\text { satisfaction can generate brand loyalty. } \\
\text { Then customers move on repurchase of } \\
\text { that particular brand. }\end{array}$} \\
\hline & & & & $\begin{array}{l}\text { Informative } \\
\text { susceptibility }\end{array}$ & & \\
\hline & & & & $\begin{array}{l}\text { Normative } \\
\text { susceptibility }\end{array}$ & & \\
\hline & & & & Brand Image & & \\
\hline & & & & Service quality & & \\
\hline \multirow[t]{6}{*}{ 23) } & \multirow{6}{*}{$\begin{array}{l}\text { Muhammad } \\
\text { Waqas Tariq } \\
\text { Chaudary } \\
\text { (2014) }\end{array}$} & \multirow{6}{*}{$\begin{array}{l}\text { The } \\
\text { determinants } \\
\text { of purchase } \\
\text { intention of } \\
\text { consumers } \\
\text { towards } \\
\text { counterfeit } \\
\text { shoes in } \\
\text { Pakistan }\end{array}$} & \multirow{6}{*}{$\begin{array}{l}\text { Empirical } \\
\text { research } \\
\text { Total } 180 \\
\text { participants out } \\
\text { of } 200 \text { completed } \\
\text { the questionnaire } \\
\text { that contained } \\
\text { two sections. }\end{array}$} & $\begin{array}{l}\text { Value } \\
\text { consciousness }\end{array}$ & \multirow[t]{6}{*}{$*$} & \multirow{6}{*}{$\begin{array}{l}\text { This study was restricted to the } \\
\text { examination of limited factors that had } \\
\text { showed some kind of significant } \\
\text { influence on the consumers' attitude } \\
\text { and purchase intentions in past studies. } \\
\text { Ethical and moral values influenced by } \\
\text { culture, nationality and other such } \\
\text { factors may be included. }\end{array}$} \\
\hline & & & & Social status & & \\
\hline & & & & $\begin{array}{l}\text { Previous } \\
\text { experience }\end{array}$ & & \\
\hline & & & & Low Price & & \\
\hline & & & & Easy access & & \\
\hline & & & & $\begin{array}{l}\text { Attitude towards } \\
\text { buying }\end{array}$ & & \\
\hline \multirow[t]{3}{*}{ 24) } & \multirow{3}{*}{$\begin{array}{l}\text { ZohrehDehda } \\
\text { shtishahrokh } \\
\text { et al (2014) }\end{array}$} & \multirow{3}{*}{$\begin{array}{l}\text { The effect of } \\
\text { country of } \\
\text { brand and } \\
\text { country of } \\
\text { manufacture }\end{array}$} & \multirow{3}{*}{$\begin{array}{l}\text { Empirical } \\
\text { research } \\
\text { Sample size }=586\end{array}$} & Country of Origin & \multirow[t]{3}{*}{$*$} & \multirow{3}{*}{$\begin{array}{l}\text { Current study limits its evaluation of } \\
\text { the country image into two parameters } \\
\text { which contains manufacture country } \\
\text { image and brand countries image. } \\
\text { Furthermore some other components of }\end{array}$} \\
\hline & & & & & & \\
\hline & & & & $\begin{array}{l}\text { Country of } \\
\text { Manufacture }\end{array}$ & & \\
\hline
\end{tabular}




\begin{tabular}{|c|c|c|c|c|c|c|}
\hline & & $\begin{array}{l}\text { on brand } \\
\text { loyalty and } \\
\text { purchase } \\
\text { intention }\end{array}$ & & Brand Loyalty & $\nLeftarrow$ & $\begin{array}{l}\text { COO such as country of design and } \\
\text { country of assemble are not considered } \\
\text { in our model. } \\
\text { Price has not been included in the } \\
\text { study, which is an important factor. }\end{array}$ \\
\hline \multirow[t]{4}{*}{$25)$} & \multirow{4}{*}{$\begin{array}{l}\text { HosseinPour } \\
\text { ahmadi\&Nar } \\
\text { gesDelafrooz } \\
\text { (2014) }\end{array}$} & \multirow{4}{*}{$\begin{array}{l}\text { Investigating } \\
\text { the country- } \\
\text { of-origin } \\
\text { image on } \\
\text { willingness to } \\
\text { buy foreign } \\
\text { products }\end{array}$} & \multirow{4}{*}{$\begin{array}{l}\text { Empirical } \\
\text { research sample, } \\
\mathrm{n}=400 \text {, Master's } \\
\text { students from the } \\
\text { University of } \\
\text { Guilan in Iran, } \\
\text { data was } \\
\text { Collected via } \\
\text { questionnaires }\end{array}$} & $\begin{array}{l}\text { Country of Origin } \\
\text { Image }\end{array}$ & \multirow[t]{2}{*}{$\$$} & \multirow{4}{*}{$\begin{array}{l}\text { The selected sample had homogeneous } \\
\text { characteristics, such as the Young and } \\
\text { educated. } \\
\text { Various other factors, such as customer } \\
\text { nationalism, political and economic } \\
\text { relations with the country-of-origin } \\
\text { were not examined. } \\
\text { Products could choose with either high } \\
\text { involvement or low involvement to } \\
\text { broaden the study area. }\end{array}$} \\
\hline & & & & $\begin{array}{l}\text { Attitudes towards } \\
\text { foreign products }\end{array}$ & & \\
\hline & & & & & $\star$ & \\
\hline & & & & $\begin{array}{l}\text { Evaluation of } \\
\text { foreign products }\end{array}$ & & \\
\hline \multirow[t]{7}{*}{ 26) } & \multirow{7}{*}{$\begin{array}{l}\text { VahidNasehi } \\
\text { far\&Seyed } \\
\text { Mohammad } \\
\text { SadiqEs- } \\
\text { haghi(2014) }\end{array}$} & \multirow{7}{*}{$\begin{array}{l}\text { Factors } \\
\text { Affecting } \\
\text { Consumer } \\
\text { Attitudes and } \\
\text { Their Impact } \\
\text { on Purchase } \\
\text { Intention of } \\
\text { Leather } \\
\text { Clothes }\end{array}$} & \multirow{7}{*}{$\begin{array}{l}\text { Empirical } \\
\text { research The } \\
\text { sample }(\mathrm{n}=398) \\
\text { include of } \\
\text { purchaser of } \\
\text { leather clothes at } \\
6 \text { shopping } \\
\text { center in Tehran. }\end{array}$} & Attitude & \multirow[t]{7}{*}{$\%$} & \multirow{7}{*}{$\begin{array}{l}\text { The research sample was selected } \\
\text { random; it does not represent the } \\
\text { general population of Iran. } \\
\text { Thus, the sample employed in this } \\
\text { study limits the generalize ability of the } \\
43 \text { study. }\end{array}$} \\
\hline & & & & Brand & & \\
\hline & & & & & & \\
\hline & & & & $\begin{array}{l}\text { Fashion } \\
\text { Involvement }\end{array}$ & & \\
\hline & & & & Social comparison & & \\
\hline & & & & $\begin{array}{l}\text { Fashion } \\
\text { innovativeness }\end{array}$ & & \\
\hline & & & & Experiential need & & \\
\hline \multirow[t]{3}{*}{ 27) } & \multirow{3}{*}{$\begin{array}{l}\text { Kaouther } \\
\text { Ben Mansour } \\
\text { et al (2014) }\end{array}$} & \multirow{3}{*}{$\begin{array}{l}\text { Online trust } \\
\text { antecedents } \\
\text { and their } \\
\text { consequences } \\
\text { on } \\
\text { purchase } \\
\text { intention: An } \\
\text { integrative } \\
\text { approach }\end{array}$} & \multirow{3}{*}{$\begin{array}{l}\text { Empirical } \\
\text { Research } \\
\text { PILOT SURVEY } \\
\text { snowball } \\
\text { sampling method } \\
\text { was applied } \\
\text { measurement of } \\
\text { personality-based } \\
\text { trust (credibility, } \\
\text { integrity and } \\
\text { benevolence) } \\
\end{array}$} & Online trust & \multirow[t]{3}{*}{$\%$} & \multirow{3}{*}{$\begin{array}{l}\text { The study findings and implications are } \\
\text { obtained from a single study that } \\
\text { examined a particular website context. } \\
\text { Thus, additional research efforts, } \\
\text { replicating the study using other } \\
\text { websites in Indonesia as well as in } \\
\text { other international contexts, are needed } \\
\text { to evaluate the validity of the } \\
\text { investigated model and to enhance the } \\
\text { generalization of the findings. }\end{array}$} \\
\hline & & & & & & \\
\hline & & & & Perceived risk & & \\
\hline \multirow[t]{4}{*}{$28)$} & \multirow[t]{4}{*}{$\begin{array}{l}\text { Laura } \\
\text { Salciuviene } \\
\text { et al (2014) }\end{array}$} & \multirow{4}{*}{$\begin{array}{l}\text { Key Drivers } \\
\text { Affecting } \\
\text { Customer } \\
\text { Intention to } \\
\text { Purchase } \\
\text { Financial } \\
\text { Services } \\
\text { Online }\end{array}$} & \multirow{4}{*}{$\begin{array}{l}\text { An online } \\
\text { questionnaire } \\
\text { was used to reach } \\
\text { respondents in a } \\
\text { transitional } \\
\text { economy. The } \\
\text { target audience } \\
\text { was active } \\
\text { Lithuanian } \\
\text { Internet users of } \\
\text { 18-65 years old. }\end{array}$} & $\begin{array}{l}\text { Perceived } \\
\text { usefulness }\end{array}$ & \multirow[t]{4}{*}{$\%$} & \multirow[t]{4}{*}{$\begin{array}{l}\text { The sample is not a probability sample } \\
\text { as the data are collected in one } \\
\text { emerging market. }\end{array}$} \\
\hline & & & & $\begin{array}{l}\text { Perceived ease of } \\
\text { use }\end{array}$ & & \\
\hline & & & & Trust & & \\
\hline & & & & Confidentially & & \\
\hline \multirow[t]{3}{*}{ 29) } & \multirow[t]{3}{*}{$\begin{array}{l}\text { A. de Leeuw } \\
\text { et al (2014) }\end{array}$} & \multirow{3}{*}{$\begin{array}{l}\text { Gender } \\
\text { Differences in } \\
\text { Psychosocial } \\
\text { Determinants } \\
\text { of University } \\
\text { Students' } \\
\text { Intentions to } \\
\text { Buy Fair } \\
\text { Trade } \\
\text { Products }\end{array}$} & \multirow{3}{*}{$\begin{array}{l}782 \\
\text { undergraduate, } \\
\text { graduate, and } \\
\text { postdoctoral } \\
\text { students } \\
\text { attending the } \\
\text { University of } \\
\text { Luxembourg } \\
\text { (413 females, } \\
369 \text { males).All } \\
\text { participants } \\
\text { aged from } 17 \text { to } \\
\text { 37years. }\end{array}$} & Attitude & \multirow[t]{3}{*}{$\%$} & \multirow{3}{*}{$\begin{array}{l}\text { The behavioral, normative, and control } \\
\text { beliefs underlying students' FT } \\
\text { consumption intentions were not } \\
\text { examined. }\end{array}$} \\
\hline & & & & Perceived Norms & & \\
\hline & & & & $\begin{array}{l}\text { Perceived behavior } \\
\text { control }\end{array}$ & & \\
\hline \multirow[t]{3}{*}{ 30) } & \multirow{3}{*}{$\begin{array}{l}\text { Waseem } \\
\text { Akbar et al } \\
(2014)\end{array}$} & \multirow{3}{*}{$\begin{array}{l}\text { Antecedents } \\
\text { Affecting } \\
\text { Customer's } \\
\text { Purchase } \\
\text { Intentions }\end{array}$} & Self- & Attitude & 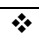 & The existing study is limited to one city \\
\hline & & & 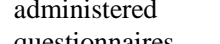 & Perceived value & & of Pakistan and it could not be the \\
\hline & & & $\begin{array}{l}\text { questionnaires } \\
\text { we collected data } \\
\text { from our } 160\end{array}$ & Perceived trust & $*$ & $\begin{array}{l}\text { demonstrative of the all citizens of } \\
\text { Pakistan. } \\
\text { Present study includes the very small }\end{array}$ \\
\hline
\end{tabular}




\begin{tabular}{|c|c|c|c|c|c|c|}
\hline & & $\begin{array}{l}\text { towards Green } \\
\text { Products }\end{array}$ & $\begin{array}{l}\text { respondents of } \\
\text { Pakistan. }\end{array}$ & $\begin{array}{l}\text { Ecological } \\
\text { Knowledge }\end{array}$ & & $\begin{array}{l}\text { sample size; the follow up researches } \\
\text { may increase the sample size and can } \\
\text { collect the data from various major } \\
\text { cities of Pakistan like Lahore, Karachi } \\
\text { and Islamabad. }\end{array}$ \\
\hline \multirow[t]{5}{*}{ 31) } & \multirow{5}{*}{$\begin{array}{l}\text { XiziXie, and } \\
\text { SirionChaipo } \\
\text { opirutana } \\
(2014)\end{array}$} & \multirow{5}{*}{$\begin{array}{l}\text { A Study of } \\
\text { Factors } \\
\text { Affecting } \\
\text { Towards } \\
\text { Young } \\
\text { Customers' } \\
\text { Purchase } \\
\text { Intention of } \\
\text { Domestic- } \\
\text { Branded } \\
\text { Smartphone in } \\
\text { Shanghai, } \\
\text { Republic of } \\
\text { China }\end{array}$} & \multirow{5}{*}{$\begin{array}{l}\text { The target } \\
\text { population is } \\
\text { university } \\
\text { students studying } \\
\text { Bachelor, Master } \\
\text { or Doctor degree } \\
\text { who intend to } \\
\text { buy Xiaomi } \\
\text { smart phone in } \\
\text { the eight national } \\
\text { universities in } \\
\text { Shanghai, } \\
\text { Republic of } \\
\text { China. A total of } \\
400 \text { data was } \\
\text { tested }\end{array}$} & $\begin{array}{l}\text { Consumer } \\
\text { aspiration }\end{array}$ & \multirow[t]{5}{*}{$\%$} & \multirow{5}{*}{$\begin{array}{l}\text { The research considered only four } \\
\text { variables, thus, other variables which } \\
\text { can influence purchase intention } \\
\text { including consumer ethnocentric, price } \\
\text { consciousness, symbolic value and } \\
\text { need for uniqueness could be explored. }\end{array}$} \\
\hline & & & & Social value & & \\
\hline & & & & Attitude & & \\
\hline & & & & $\begin{array}{l}\text { Price } \\
\text { consciousness }\end{array}$ & & \\
\hline & & & & $\begin{array}{l}\text { Consumer } \\
\text { uncertainty }\end{array}$ & & \\
\hline \multirow[t]{2}{*}{$\begin{array}{l}32) \\
(13,8 \\
)\end{array}$} & \multirow[t]{2}{*}{$\begin{array}{l}\text { Jing Li, Jiang } \\
\mathrm{Li} \text {, } \\
\text { YongbiaoZhe } \\
\text { ng(2013) }\end{array}$} & \multirow{2}{*}{$\begin{array}{l}\text { Corporate } \\
\text { Image } \\
\text { Cognition } \\
\text { Influence } \\
\text { Perceived } \\
\text { Quality and } \\
\text { Purchase } \\
\text { Intention } \\
\text { Empirical } \\
\text { Research }\end{array}$} & \multirow[t]{2}{*}{$\begin{array}{l}\text { Empirical } \\
\text { Research } \\
250 \\
\text { Questionnaire }\end{array}$} & $\begin{array}{l}\text { Corporate Image } \\
\text { Cognition }\end{array}$ & \multirow[t]{2}{*}{$\%$} & $\begin{array}{l}\text { This study only selected the telecom } \\
\text { service providers } 3 \mathrm{G} \text { service brand, } \\
\text { and in real life different industry } \\
\text { products are different, its consumer } \\
\text { perception is differ-ant, and so the }\end{array}$ \\
\hline & & & & Perceived Quality & & $\begin{array}{l}\text { promoting significance of conclusion } \\
\text { fell. } \\
\text { Research should be expanded to the } \\
\text { selection of the industry, covering } \\
\text { more categories of products, such as } \\
\text { clothing, fast consuming goods and } \\
\text { other brands of product category. }\end{array}$ \\
\hline \multirow[t]{3}{*}{ 33) } & \multirow{3}{*}{$\begin{array}{l}\text { ArunThamiz } \\
\text { hvanan\& } \\
\text { M.J. } \\
\text { Xavier(2013) }\end{array}$} & \multirow{3}{*}{$\begin{array}{l}\text { Determinants } \\
\text { of customers' } \\
\text { online } \\
\text { purchase } \\
\text { intention: an } \\
\text { empirical } \\
\text { study in India }\end{array}$} & \multirow{3}{*}{$\begin{array}{l}\text { Empirical } \\
\text { research } \\
\text { Online survey } \\
\text { based on } 95 \text { valid } \\
\text { response }\end{array}$} & Online trust & \multirow{3}{*}{$*$} & \multirow{3}{*}{$\begin{array}{l}\text { The convenience sample of } 95 \mathrm{MBA} \\
\text { graduates may not be representative. } \\
\text { Hence the finding may not be } \\
\text { generalizable though internet savvy } \\
\text { students contribute to a major } \\
\text { percentage of online shoppers in India. }\end{array}$} \\
\hline & & & & $\begin{array}{l}\text { Prior online } \\
\text { purchase } \\
\text { experience }\end{array}$ & & \\
\hline & & & & $\begin{array}{l}\text { Shopping } \\
\text { orientation }\end{array}$ & & \\
\hline \multirow[t]{3}{*}{ 34) } & \multirow{3}{*}{$\begin{array}{l}\text { BengSooOng } \\
\text { (2013) }\end{array}$} & \multirow{3}{*}{$\begin{array}{l}\text { Determinants } \\
\text { of Purchase } \\
\text { intentions and } \\
\text { Stock-Piling } \\
\text { Tendency of } \\
\text { Bonus Packs }\end{array}$} & \multirow{3}{*}{$\begin{array}{l}\text { Students in two } \\
\text { undergraduate } \\
\text { marketing classes } \\
\text { at a large } \\
\text { university were } \\
\text { assigned to } \\
\text { distribute the } \\
\text { questionnaires to } \\
\text { consumers }\end{array}$} & Bonus Packs & \multirow[t]{3}{*}{$\%$} & \multirow{3}{*}{$\begin{array}{l}\text { Purchase intentions and stock-piling } \\
\text { tendencies of bonus packs were each } \\
\text { measured via a single item. } \\
\text { Multiple- measures could be used for } \\
\text { better result. } \\
\text { The purchase intention models R } \\
\text { square was fairly small. } \\
\text { The findings may not apply to other } \\
\text { types of bonus pack (e.g. buy- four- } \\
\text { get- one- free). }\end{array}$} \\
\hline & & & & $\begin{array}{l}\text { Coupons } \\
\text { Price discounts }\end{array}$ & & \\
\hline & & & & Rebates & & \\
\hline \multirow[t]{4}{*}{ 35) } & \multirow[t]{4}{*}{$\begin{array}{l}\text { BahmanHaji } \\
\text { pour et al } \\
(2013)\end{array}$} & \multirow{4}{*}{$\begin{array}{l}\text { Effect of } \\
\text { Marketing } \\
\text { Factors on } \\
\text { Brand } \\
\text { Relationship } \\
\text { Equity and } \\
\text { Affects the } \\
\text { Customers' } \\
\text { Purchase } \\
\text { Intention }\end{array}$} & \multirow{4}{*}{$\begin{array}{l}\text { Empirical } \\
\text { research } \\
522 \text { consumers } \\
\text { of Tehran, capital } \\
\text { of Iran }\end{array}$} & $\begin{array}{l}\text { Advertising } \\
\text { Price } \\
\end{array}$ & \multirow[t]{3}{*}{$*$} & \multirow{4}{*}{$\begin{array}{l}\text { This model could be investigated for } \\
\text { the domestic market conditions in Iran } \\
\text { or other countries. } \\
\text { This study could be implemented in } \\
\text { other cities and societies with different } \\
\text { cultures. } \\
\text { The current study is applicable for } \\
\text { other product and industries. }\end{array}$} \\
\hline & & & & Promotion & & \\
\hline & & & & Perceived quality & & \\
\hline & & & & Brand relationship & & \\
\hline \multirow[t]{4}{*}{ 36) } & \multirow{4}{*}{$\begin{array}{l}\text { Jiyoung Kim } \\
\text { \& Sharron J. } \\
\text { Lennon } \\
(2013)\end{array}$} & \multirow{4}{*}{$\begin{array}{l}\text { Effects of } \\
\text { reputation and } \\
\text { website } \\
\text { quality on } \\
\text { online } \\
\text { consumers' } \\
\text { emotion, } \\
\text { perceived risk } \\
\text { and purchase } \\
\text { intention }\end{array}$} & \multirow{4}{*}{$\begin{array}{l}\text { Empirical } \\
\text { research } \\
219 \\
\text { questionnaire } \\
\text { SEM Model }\end{array}$} & Reputation & \multirow[t]{4}{*}{$\%$} & \multirow{4}{*}{$\begin{array}{l}\text { The use of a convenience sample, } \\
\text { which resulted in a majority of female } \\
\text { respondents who identified apparel } \\
\text { online stores as their most visited web } \\
\text { site. } \\
\text { This study did not differentiate } \\
\text { multichannel retailers and pure online } \\
\text { retailers in our research model. } \\
\text { However, there might be a significant } \\
\text { difference between the two types of } \\
\text { retailers in terms of how consumers }\end{array}$} \\
\hline & & & & Website quality & & \\
\hline & & & & Emotions & & \\
\hline & & & & Perceived risk & & \\
\hline
\end{tabular}




\begin{tabular}{|c|c|c|c|c|c|c|}
\hline & & & & & & $\begin{array}{l}\text { process the two different stimuli } \\
\text { (reputation and web site quality) in } \\
\text { their decision making process. }\end{array}$ \\
\hline \multirow[t]{3}{*}{ 37) } & \multirow[t]{3}{*}{$\begin{array}{l}\text { Amir } \\
\text { Nasermoadel } \\
\text { i et al (2013) }\end{array}$} & \multirow{3}{*}{$\begin{array}{l}\text { Evaluating the } \\
\text { Impacts of } \\
\text { Customer } \\
\text { Experience on } \\
\text { Purchase } \\
\text { Intention }\end{array}$} & \multirow[t]{3}{*}{$\begin{array}{l}\text { Empirical } \\
\text { research } \\
330 \text { respondents }\end{array}$} & $\begin{array}{l}\text { Emotional } \\
\text { experience }\end{array}$ & \multirow[t]{3}{*}{$\%$} & \multirow{3}{*}{$\begin{array}{l}\text { The adoption of cross-sectional data } \\
\text { may not able to explain the customer } \\
\text { experience according to the observed } \\
\text { changes in pattern and the causality of } \\
\text { the purchase intention across a long } \\
\text { period of time. } \\
\text { The adoption of judgmental sampling } \\
\text { method in this research has also limited } \\
\text { the generalizable of the research } \\
\text { findings. }\end{array}$} \\
\hline & & & & Social experience & & \\
\hline & & & & Sensory experience & & \\
\hline \multirow[t]{3}{*}{ 38) } & \multirow{3}{*}{$\begin{array}{l}\text { Chieh-min } \\
\text { chou et al } \\
(2013)\end{array}$} & \multirow{3}{*}{$\begin{array}{l}\text { Factors } \\
\text { Affecting } \\
\text { Purchase } \\
\text { Intention of } \\
\text { Online Game } \\
\text { Prepayment } \\
\text { Card - } \\
\text { Evidence from } \\
\text { Thailand }\end{array}$} & \multirow{3}{*}{$\begin{array}{l}\text { Empirical } \\
\text { research } \\
335 \text { Respondents } \\
\text { data from } \\
\text { Thailand }\end{array}$} & Perceived value & \multirow{3}{*}{$\%$} & \multirow{3}{*}{$\begin{array}{l}\text { The research hypotheses were only } \\
\text { tested by Thailand data. } \\
\text { In order to extent the external validity } \\
\text { of this study, other country's data } \\
\text { should be collected for testing and } \\
\text { comparison. }\end{array}$} \\
\hline & & & & Price & & \\
\hline & & & & Promotion & & \\
\hline \multirow[t]{3}{*}{ 39) } & \multirow{3}{*}{$\begin{array}{l}\text { Sathiswaran } \\
\text { Uthamaputha } \\
\text { ran, and } \\
\text { Muslim } \\
\text { Amin (2013) }\end{array}$} & \multirow{3}{*}{$\begin{array}{l}\text { Green Product } \\
\text { Positioning } \\
\text { And Purchase } \\
\text { Intention in } \\
\text { Malaysia }\end{array}$} & \multirow{3}{*}{$\begin{array}{l}\text { This paper } \\
\text { constitutes the } \\
\text { quantitative } \\
\text { results of } \\
\text { customers } \\
\text { through } \\
\text { questionnaires } \\
\text { with the size of } \\
400 \text { respondents }\end{array}$} & Product Attributes & \multirow[t]{3}{*}{$\nLeftarrow$} & \multirow{3}{*}{$\begin{array}{l}\text { A major limitation of this study is } \\
\text { respondent's lack of green knowledge } \\
\text { and awareness of the green products. } \\
\text { Different knowledge of the green } \\
\text { concepts among the respondents affects } \\
\text { the questionnaire that answered. } \\
\text { Another limitation of the study is the } \\
\text { effectiveness of emotional benefits } \\
\text { which is not completely tested in this } \\
\text { research as Malaysia is a multicultural } \\
\text { country having vast ethnic citizen. }\end{array}$} \\
\hline & & & & $\begin{array}{l}\text { Functional } \\
\text { attributes }\end{array}$ & & \\
\hline & & & & Emotional benefits & & \\
\hline \multirow[t]{4}{*}{ 40) } & \multirow[t]{4}{*}{$\begin{array}{l}\text { Carmen } \\
\text { Adina Pastiu } \\
(2013)\end{array}$} & \multirow{4}{*}{$\begin{array}{l}\text { Green } \\
\text { Purchase } \\
\text { intentions of } \\
\text { Romanian } \\
\text { consumers }\end{array}$} & \multirow{4}{*}{$\begin{array}{l}\text { The study on a } \\
\text { sample of } 110 \\
\text { persons led to the } \\
\text { identification of } \\
\text { key factors } \\
\text { influencing the } \\
\text { GPI and the } \\
\text { dividing } \\
\text { population } \\
\text { variables under } \\
\text { investigation } \\
\text { were age, } \\
\text { gender and } \\
\text { education. }\end{array}$} & $\begin{array}{l}\text { Perceived Product } \\
\text { Price }\end{array}$ & \multirow[t]{4}{*}{$\%$} & \multirow[t]{4}{*}{$\begin{array}{l}\text { The limits of this study are related to } \\
\text { the sample size and the sampled } \\
\text { population. }\end{array}$} \\
\hline & & & & $\begin{array}{l}\text { Perceived Product } \\
\text { quality }\end{array}$ & & \\
\hline & & & & $\begin{array}{l}\text { Organization's } \\
\text { Green Image }\end{array}$ & & \\
\hline & & & & $\begin{array}{l}\text { Environmental } \\
\text { Knowledge }\end{array}$ & & \\
\hline \multirow[t]{2}{*}{ 41) } & \multirow{2}{*}{$\begin{array}{l}\text { Prof. Dr. } \\
\text { Muhammad } \\
\text { Ehsan Malik } \\
\text { et al (2013) }\end{array}$} & \multirow{2}{*}{$\begin{array}{l}\text { Importance of } \\
\text { Brand } \\
\text { Awareness } \\
\text { and Brand } \\
\text { Loyalty in } \\
\text { assessing } \\
\text { Purchase } \\
\text { Intentions of } \\
\text { Consumer }\end{array}$} & \multirow{2}{*}{$\begin{array}{l}\text { Empirical } \\
\text { research } \\
350 \\
\text { questionnaire in } \\
\text { different cities of } \\
\text { Punjab(clothing } \\
\text { customer of } \\
\text { fabrics) }\end{array}$} & Brand Awareness & \multirow[t]{2}{*}{$\%$} & \multirow{2}{*}{$\begin{array}{l}\text { The paper mainly focuses on clothing } \\
\text { industry. So the findings are limited to } \\
\text { clothing sector. } \\
\text { Therefore it is obvious that researchers } \\
\text { didn't have the access to top } \\
\text { management which could to identify } \\
\text { the type of strategies adopted by the } \\
\text { companies to enhance the purchase } \\
\text { intention of their brands }\end{array}$} \\
\hline & & & & Brand Loyalty & & \\
\hline \multirow[t]{3}{*}{ 42) } & \multirow{3}{*}{$\begin{array}{l}\text { Dina Gamal } \\
\text { El Din and } \\
\text { Farid El Sahn } \\
(2013)\end{array}$} & \multirow{3}{*}{$\begin{array}{l}\text { Measuring the } \\
\text { factors } \\
\text { affecting } \\
\text { Egyptian } \\
\text { consumers' } \\
\text { intentions to } \\
\text { purchase } \\
\text { global luxury } \\
\text { fashion brands }\end{array}$} & \multirow{3}{*}{$\begin{array}{l}385 \\
\text { questionnaires } \\
\text { were used in the } \\
\text { statistical } \\
\text { analysis. } \\
\text { Convenience and } \\
\text { snowball } \\
\text { sampling is used. }\end{array}$} & Personal values & \multirow[t]{3}{*}{$\%$} & \multirow{3}{*}{$\begin{array}{l}\text { The sample was selected from } 2 \\
\text { regions in the country (Cairo and } \\
\text { Alexandria) and the number of } \\
\text { participants was low which would } \\
\text { influence the generalizability of the } \\
\text { results to the whole country. } \\
\text { Therefore study should focus on the } \\
\text { demographic and geographic attributes } \\
\text { to improve the validity of the results. } \\
\text { The study should be replicated in } \\
\text { different countries to check if the } \\
\text { results from different cultures are the } \\
\text { same. }\end{array}$} \\
\hline & & & & $\begin{array}{l}\text { Demographic } \\
\text { Age }\end{array}$ & & \\
\hline & & & & Self-Image & & \\
\hline 43) & Wasim & Antecedents & Empirical & Ethnocentrisms & $\$$ & Small sample size and confined area \\
\hline
\end{tabular}




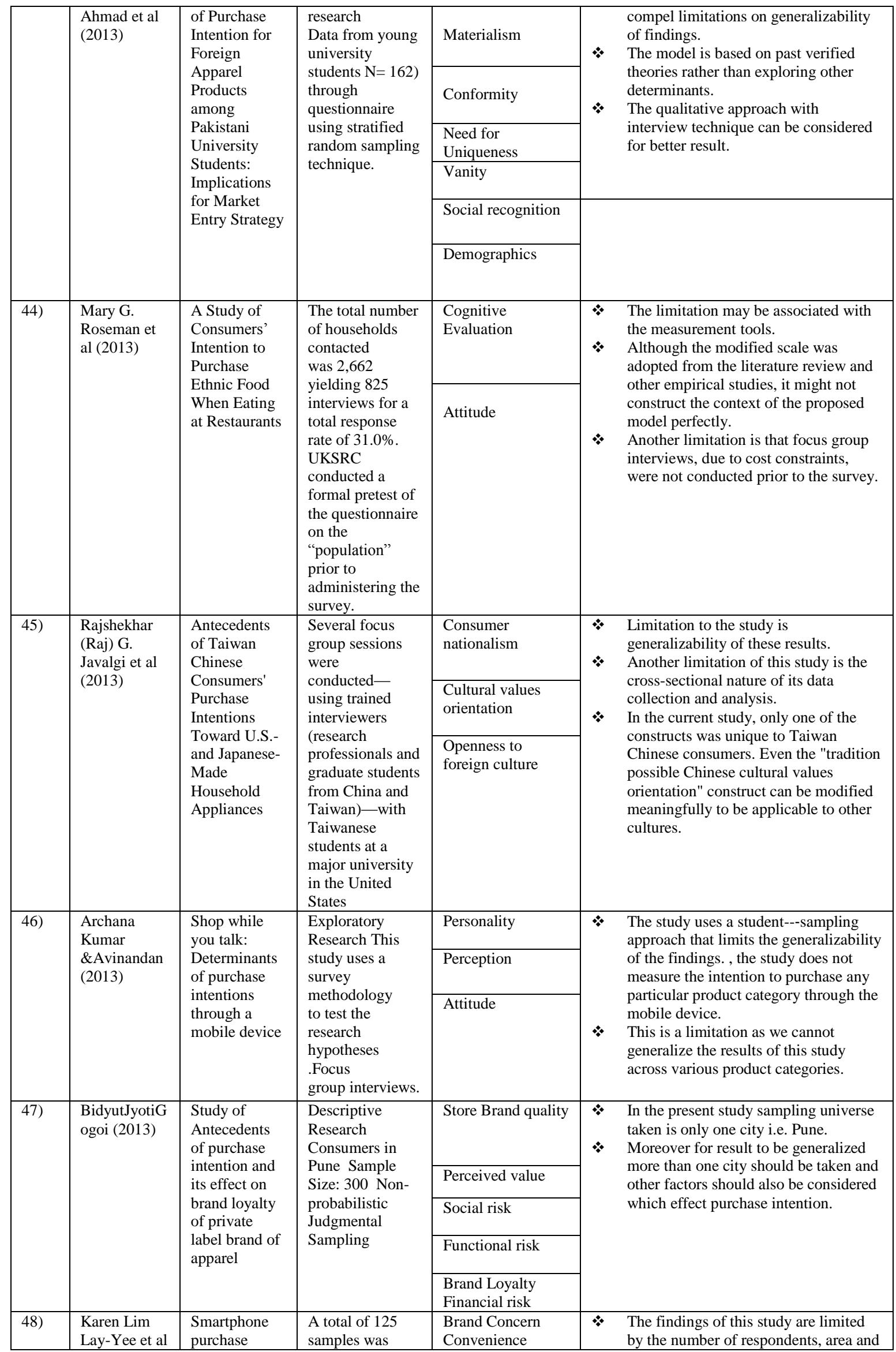




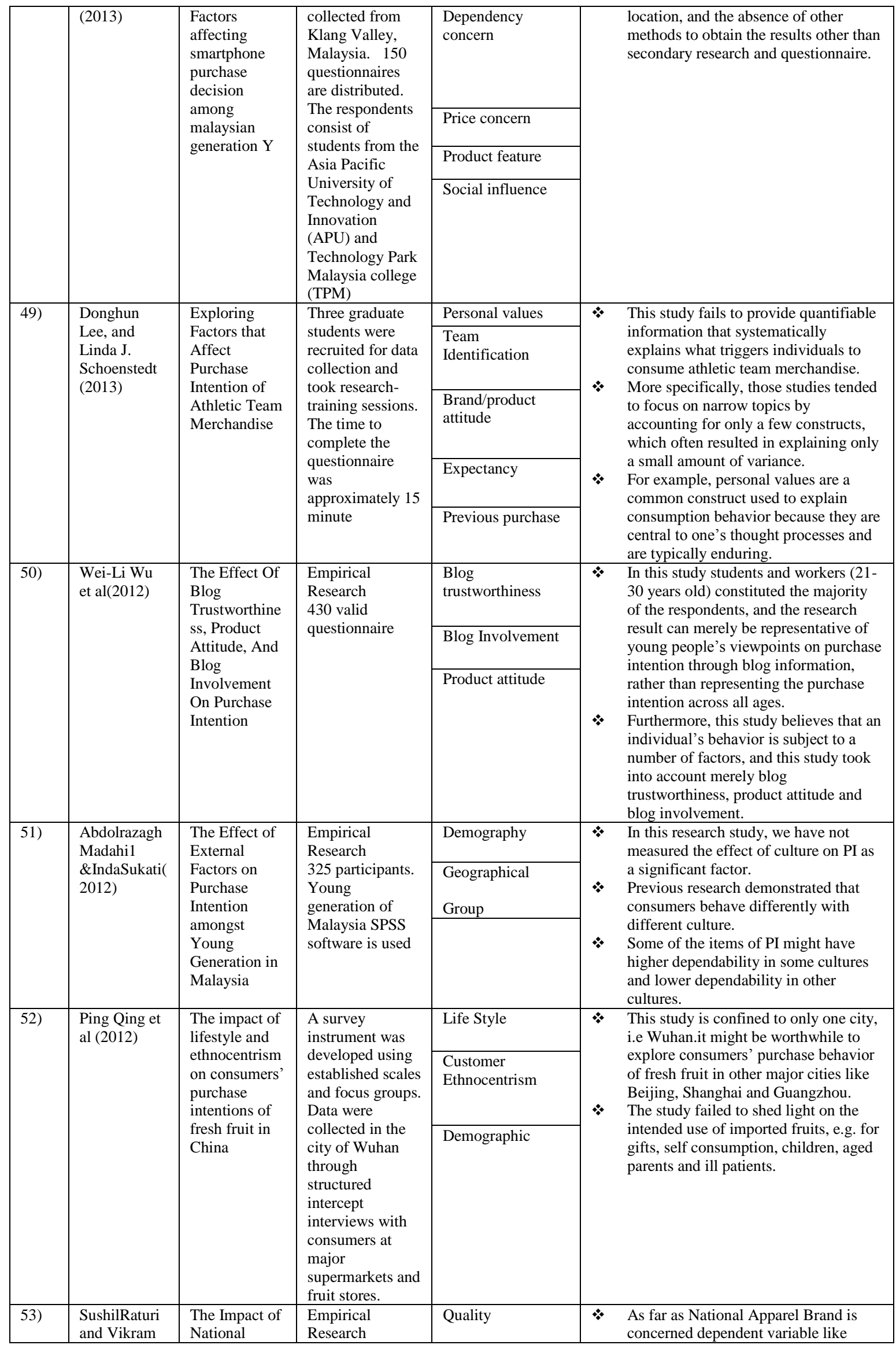




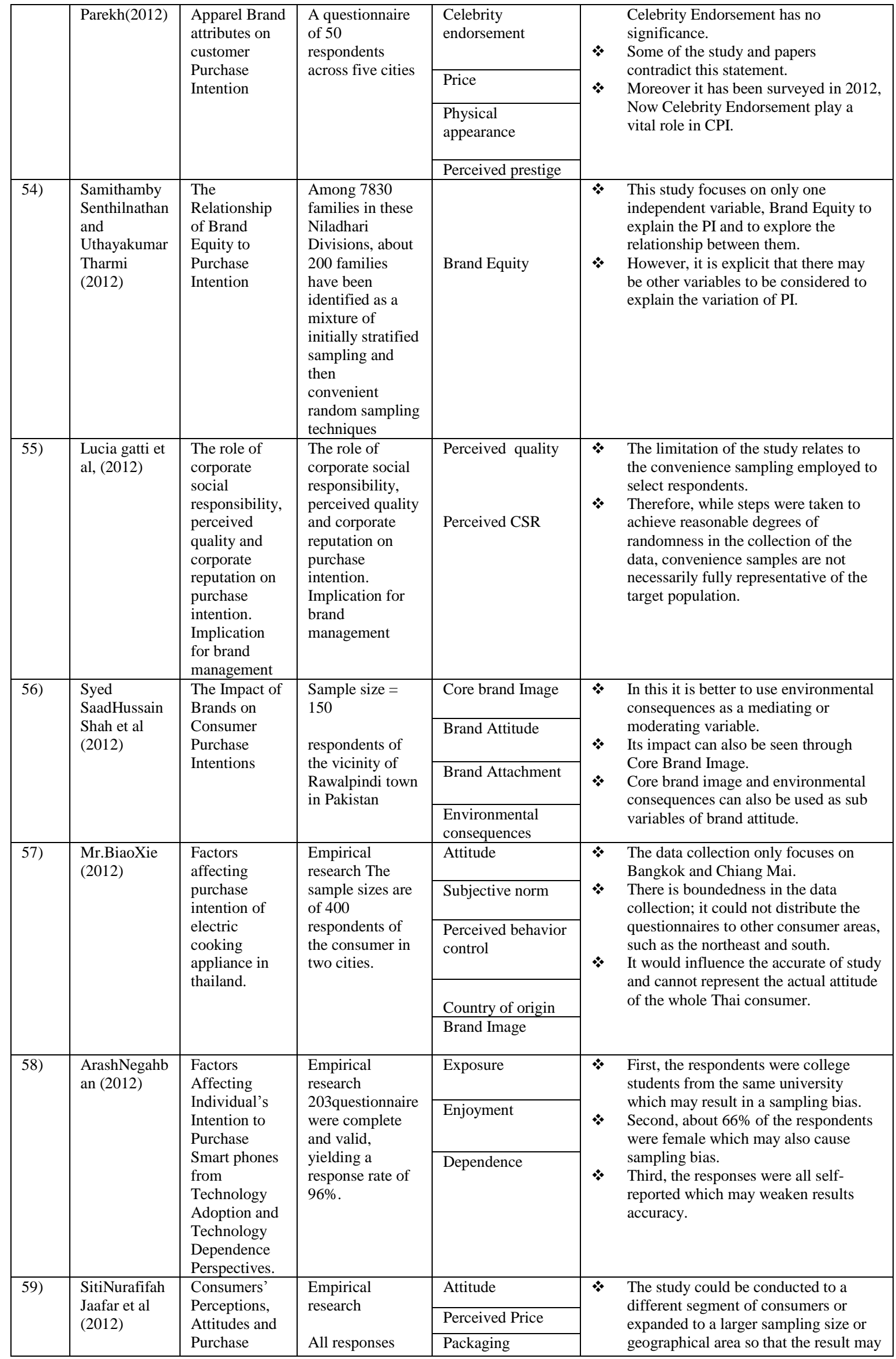




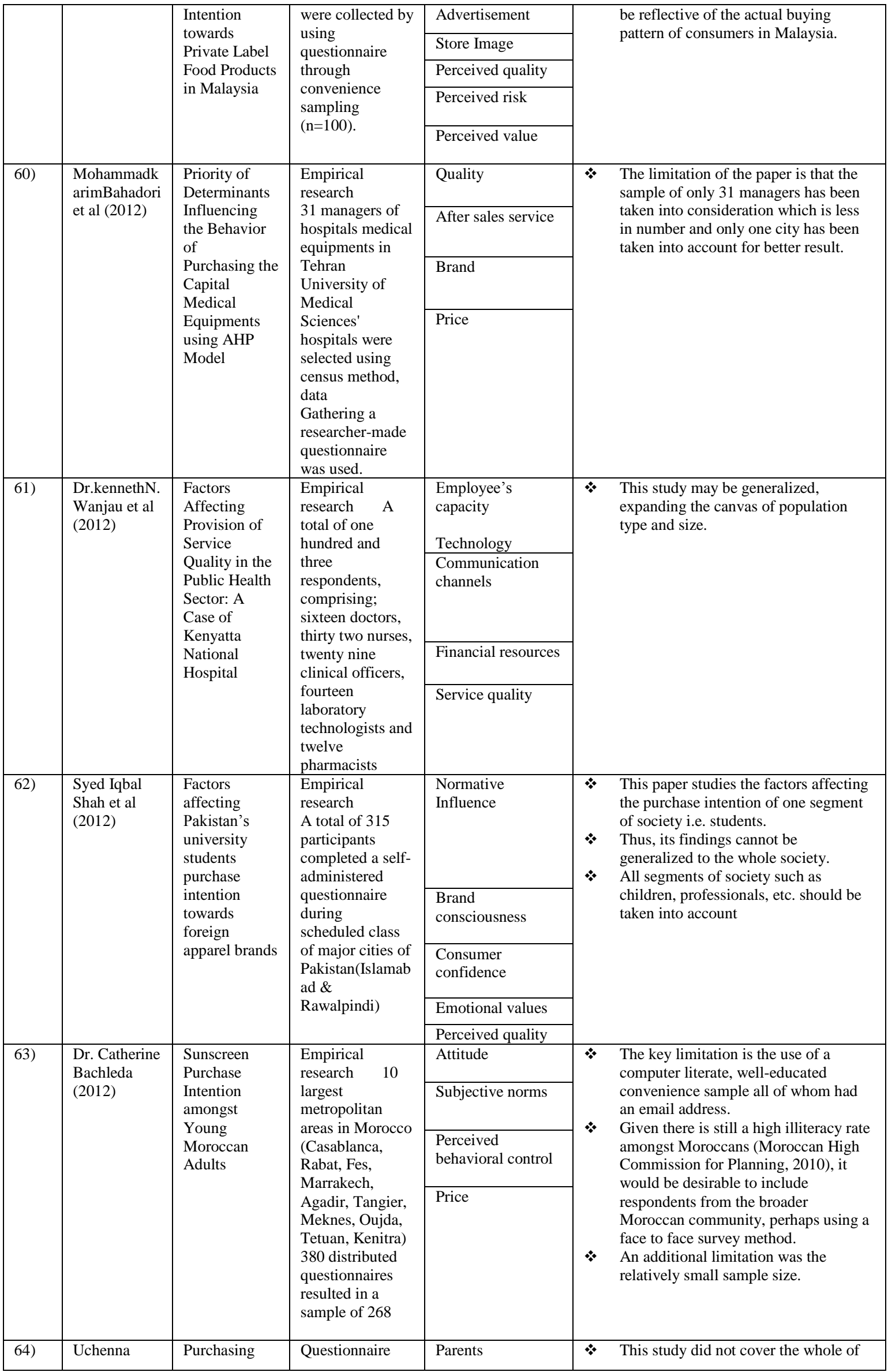




\begin{tabular}{|c|c|c|c|c|c|c|}
\hline & \multirow{3}{*}{$\begin{array}{l}\text { Cyril Eze et } \\
\text { al (2012) }\end{array}$} & \multirow{3}{*}{$\begin{array}{l}\text { Designer } \\
\text { Label } \\
\text { Apparels: The } \\
\text { Role of } \\
\text { Reference } \\
\text { Groups }\end{array}$} & \multirow{3}{*}{$\begin{array}{l}\text { survey } 248 \\
\text { valid responses } \\
\text { generated } \\
\text { through personal } \\
\text { administration. }\end{array}$} & Peers & \multirow[b]{3}{*}{$\%$} & \multirow{3}{*}{$\begin{array}{l}\text { Malaysia. } \\
\text { Other variables that may be considered } \\
\text { as moderators include Perceived risk, } \\
\text { prior knowledge and other attitudinal } \\
\text { or socioeconomic variables. } \\
\text { Moreover, in this study terms siblings } \\
\text { and parents has been used, which may } \\
\text { appear less scientific. } \\
\text { In addition, most of the participants in } \\
\text { this study were students, whose } \\
\text { purchasing power may be weak. }\end{array}$} \\
\hline & & & & Celebrities & & \\
\hline & & & & Siblings & & \\
\hline \multirow[t]{5}{*}{$\begin{array}{l}65) \\
(12,6 \\
5)\end{array}$} & \multirow[t]{5}{*}{$\begin{array}{l}\text { Seok Kang } \\
(2012)\end{array}$} & \multirow{5}{*}{$\begin{array}{l}\text { The Influence } \\
\text { of Multimedia } \\
\text { Exposure on } \\
\text { Purchase } \\
\text { Intention of } \\
\text { Sponsored } \\
\text { Products: The } \\
\text { Case of the } \\
\text { 2010 FIFA } \\
\text { World Cup }\end{array}$} & \multirow{5}{*}{$\begin{array}{l}\text { Empirical } \\
\text { Research } \\
\text { Sample size }, \mathrm{n}= \\
241\end{array}$} & $\begin{array}{l}\text { Multimedia } \\
\text { exposure }\end{array}$ & \multirow[t]{5}{*}{$\%$} & \multirow{5}{*}{$\begin{array}{l}\text { Sample size is not appropriate. } \\
\text { A cross-cultural study might need to be } \\
\text { conducted to know how the FIFA } \\
\text { World Cup and its sponsors influence } \\
\text { on the target market in different } \\
\text { cultures with different generations to } \\
\text { persuade their attitude, subjective } \\
\text { norm, and perceived behavioral } \\
\text { control. } \\
\text { The low response rate is another } \\
\text { limitation of the study which limits the } \\
\text { generalization of the study results }\end{array}$} \\
\hline & & & & $\begin{array}{l}\text { Attitude towards } \\
\text { brands }\end{array}$ & & \\
\hline & & & & Subjective Norms & & \\
\hline & & & & $\begin{array}{l}\text { Perceived behavior } \\
\text { control }\end{array}$ & & \\
\hline & & & & Past experience & & \\
\hline \multirow[t]{4}{*}{ 66) } & \multirow{4}{*}{$\begin{array}{l}\text { Nguyen } \\
\text { ThanhHuong } \\
\text { (2012) }\end{array}$} & \multirow{4}{*}{$\begin{array}{l}\text { Key factors } \\
\text { affecting } \\
\text { consumers } \\
\text { purchase } \\
\text { intention A } \\
\text { study of safe } \\
\text { vegetable in } \\
\text { Ho Chi Minh } \\
\text { City, Vietnam }\end{array}$} & \multirow{4}{*}{$\begin{array}{l}\text { The survey in the } \\
\text { form of } \\
\text { questionnaire } \\
\text { was delivered to } \\
\text { the consumers by } \\
\text { both } \\
\text { Electronic survey } \\
\text { and handout } \\
\text { survey The } \\
\text { sample size used } \\
\text { for data analysis } \\
\text { is } 412 \text { samples in } \\
\text { which } 27,4 \% \text { is } \\
\text { male and } 72,6 \% \\
\text { is female. }\end{array}$} & Trust & \multirow[t]{4}{*}{$*$} & \multirow{4}{*}{$\begin{array}{l}\text { In the study there could be other major } \\
\text { factors which could place high impact } \\
\text { on consumer purchase intention such } \\
\text { as store, origin of safe vegetable, price } \\
\text { premium of safe vegetable compared to } \\
\text { conventional vegetable, and brand. }\end{array}$} \\
\hline & & & & Price perception & & \\
\hline & & & & Appearance & & \\
\hline & & & & Demographic & & \\
\hline \multirow[t]{3}{*}{ 67) } & \multirow[t]{3}{*}{$\begin{array}{l}\text { Zhongjun } \\
\text { Tang et } \\
\text { al,(2011) }\end{array}$} & \multirow{3}{*}{$\begin{array}{l}\text { Antecedents } \\
\text { of intention to } \\
\text { purchase mass } \\
\text { customized } \\
\text { products }\end{array}$} & \multirow{3}{*}{$\begin{array}{l}\text { Empirical } \\
\text { Research Sample } \\
\text { size }=779 \\
\text { respondents }\end{array}$} & Attitude & \multirow[t]{3}{*}{$\%$} & \multirow{3}{*}{$\begin{array}{l}\text { This study focused on factors } \\
\text { influencing intention to purchase } \\
\text { customized PC and their effect levels, } \\
\text { but excluded relationship between } \\
\text { intention and actual purchase. } \\
\text { Other constructs should be added } \\
\text { because } 49.5 \text { percent variance of } \\
\text { endogenous construct is unexplained. }\end{array}$} \\
\hline & & & & Self- Attitude & & \\
\hline & & & & Subjective Norms & & \\
\hline \multirow[t]{4}{*}{ 68) } & \multirow{4}{*}{$\begin{array}{l}\text { AnantSaxena } \\
\text { (2011) }\end{array}$} & \multirow{4}{*}{$\begin{array}{l}\text { Blogs and } \\
\text { their impact } \\
\text { on Purchase } \\
\text { intention: A } \\
\text { structural } \\
\text { Equation } \\
\text { Modelling } \\
\text { Approach }\end{array}$} & \multirow{4}{*}{$\begin{array}{l}\text { Empirical } \\
\text { research } \\
\text { Survey data 0f } \\
290 \\
\text { questionnaire } \\
\text { was collected } \\
\text { from MBA } \\
\text { students of Delhi } \\
\text { and NCR, } 230 \\
\text { says yes. }\end{array}$} & Credibility & \multirow[t]{4}{*}{$*$} & \multirow{4}{*}{$\begin{array}{l}\text { The sample is self-selected as } \\
\text { convenience sampling is employed. } \\
\text { Moreover, as the subjects are blog } \\
\text { users in India, their culture, lifestyle; } \\
\text { and purchase behavior may differ from } \\
\text { other countries. }\end{array}$} \\
\hline & & & & Attitude & & \\
\hline & & & & Social Norm & & \\
\hline & & & & Intention & & \\
\hline \multirow[t]{2}{*}{ 69) } & \multirow[t]{2}{*}{$\begin{array}{l}\text { Ho } \\
\text { HuyTuu\&Sv } \\
\text { einOttar } \\
\text { Olsen (2011) }\end{array}$} & \multirow{2}{*}{$\begin{array}{l}\text { Certainty, risk } \\
\text { and } \\
\text { knowledge in } \\
\text { the } \\
\text { satisfaction- } \\
\text { purchase } \\
\text { intention }\end{array}$} & \multirow[t]{2}{*}{$\begin{array}{l}\text { Empirical } \\
\text { Research } \\
120 \text { participants }\end{array}$} & Satisfaction & \multirow[t]{2}{*}{$\%$} & \multirow{2}{*}{$\begin{array}{l}\text { This study used only one new food } \\
\text { product and university students for the } \\
\text { experiment, which may generate } \\
\text { limitations to research. } \\
\text { Therefore the study should extend the } \\
\text { model to include more moderators as } \\
\text { well as use an experimental design }\end{array}$} \\
\hline & & & & $\begin{array}{l}\text { Manipulated } \\
\text { Knowledge }\end{array}$ & & \\
\hline
\end{tabular}




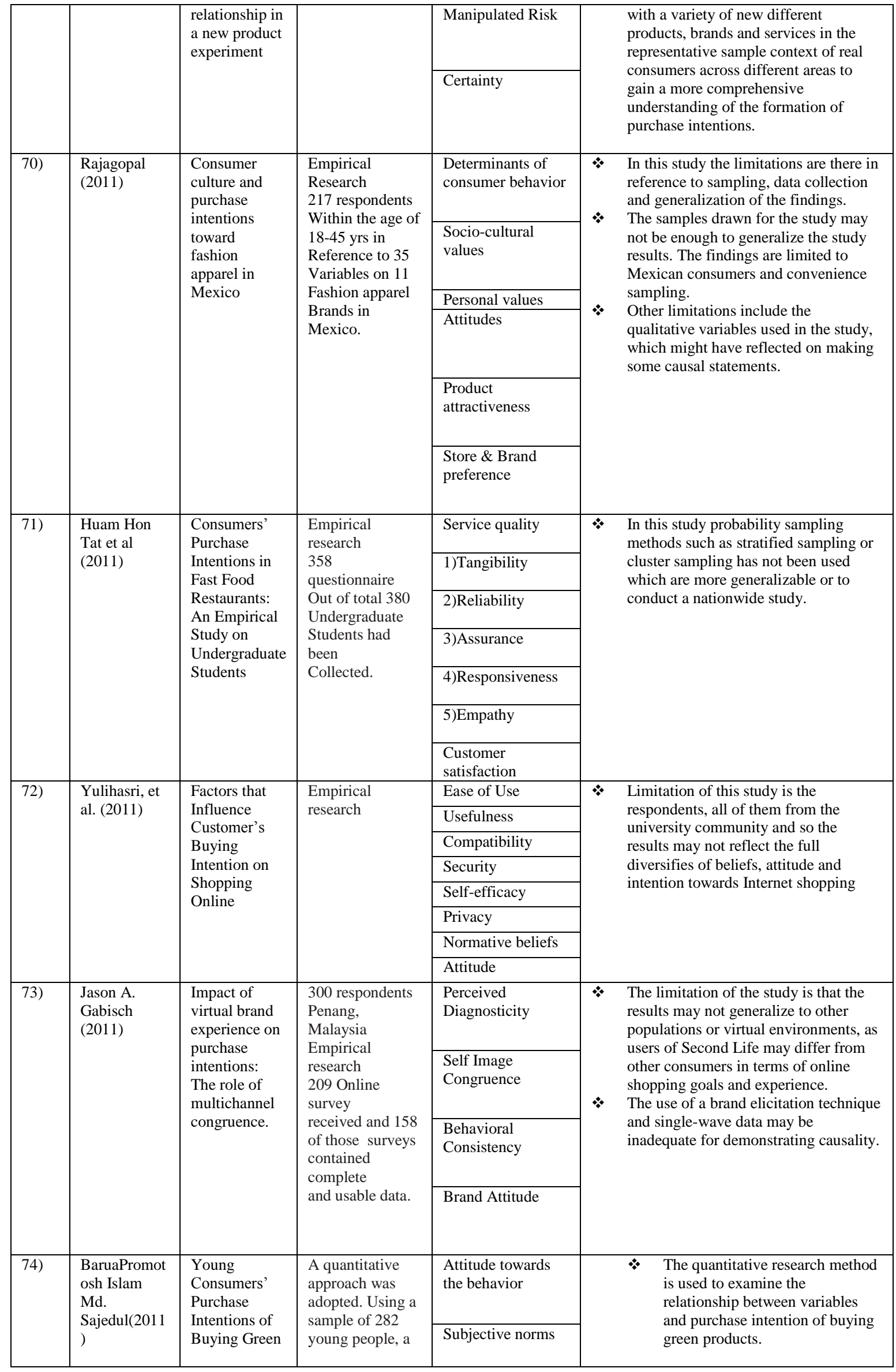




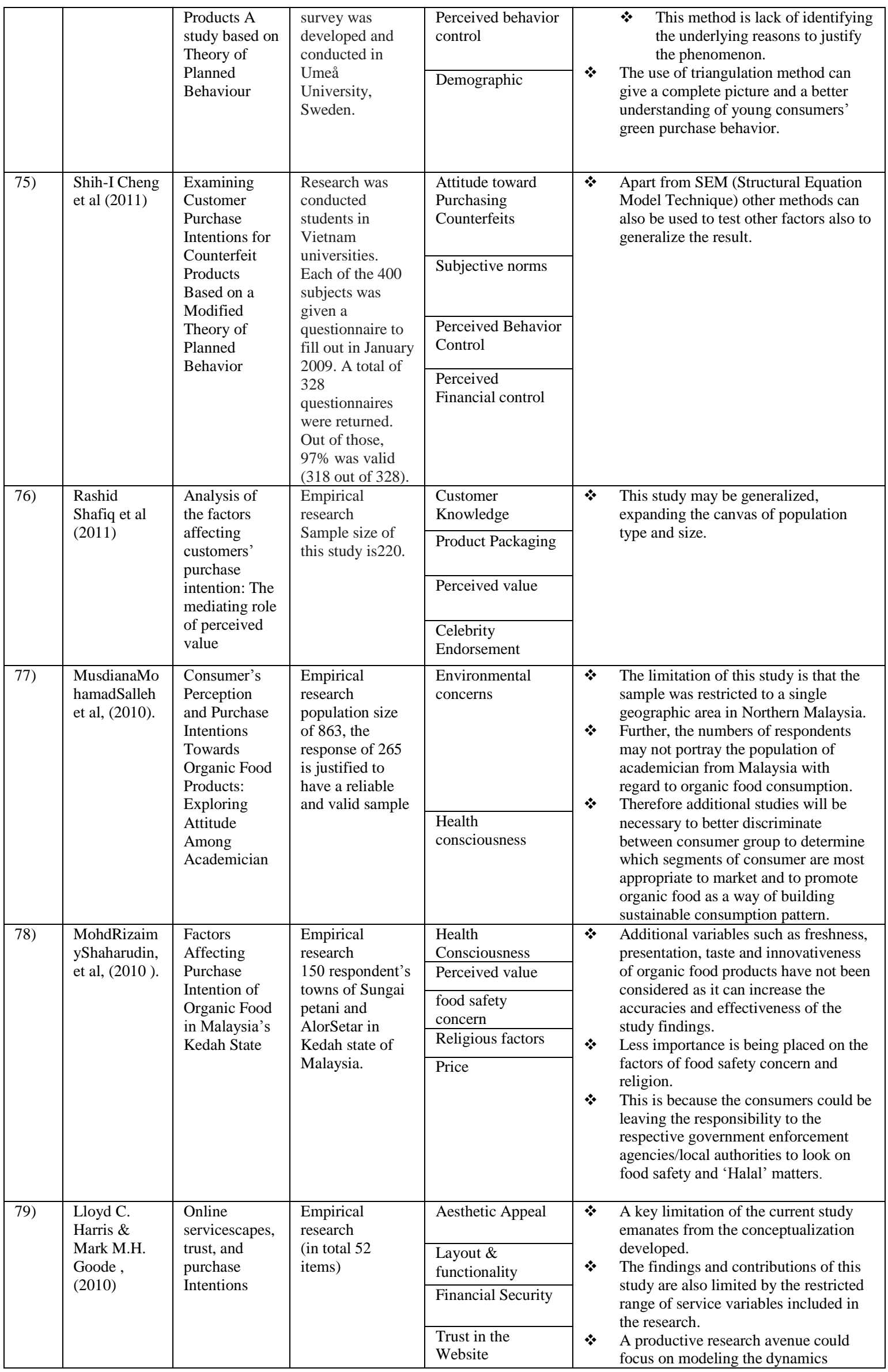




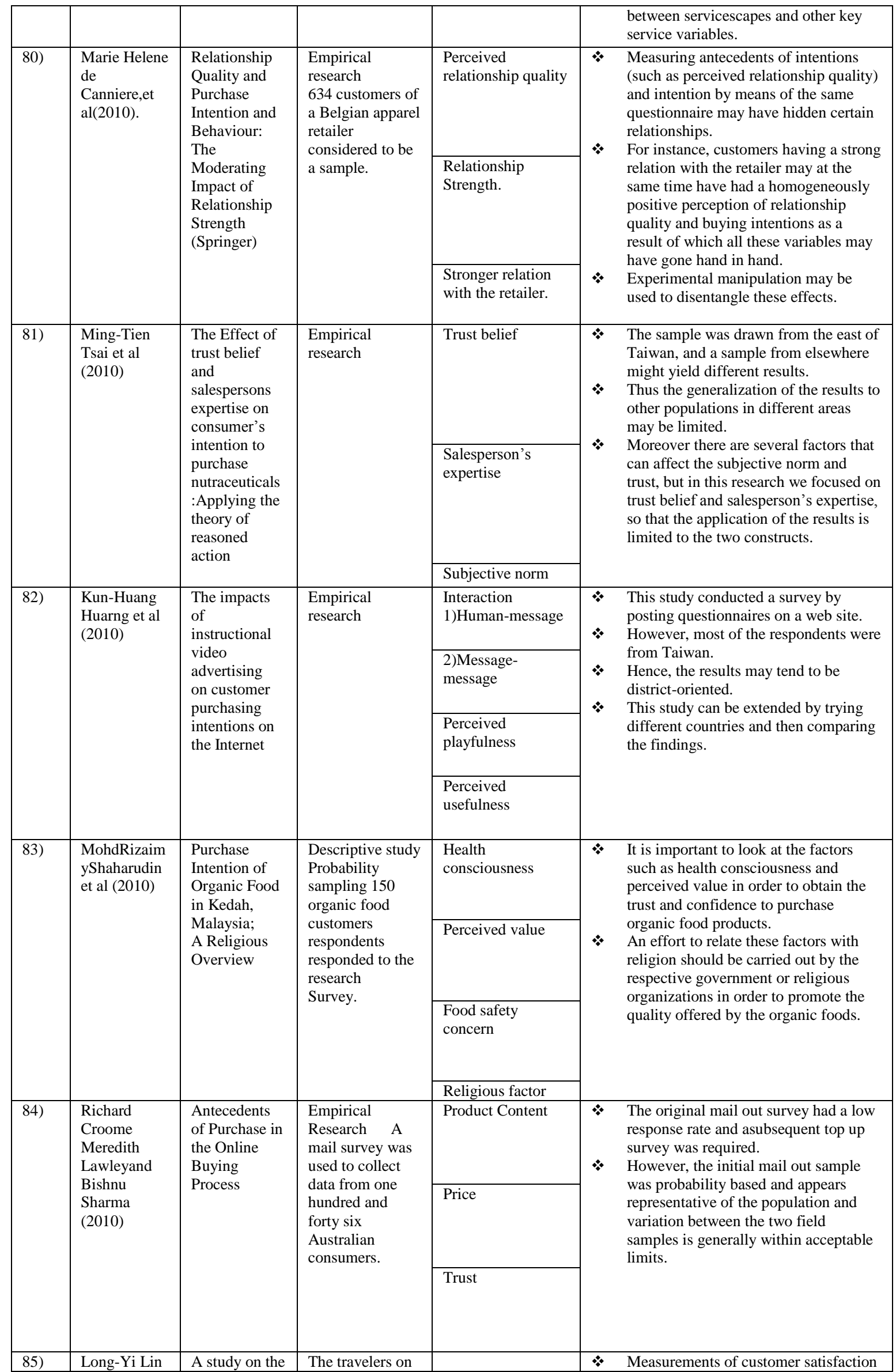




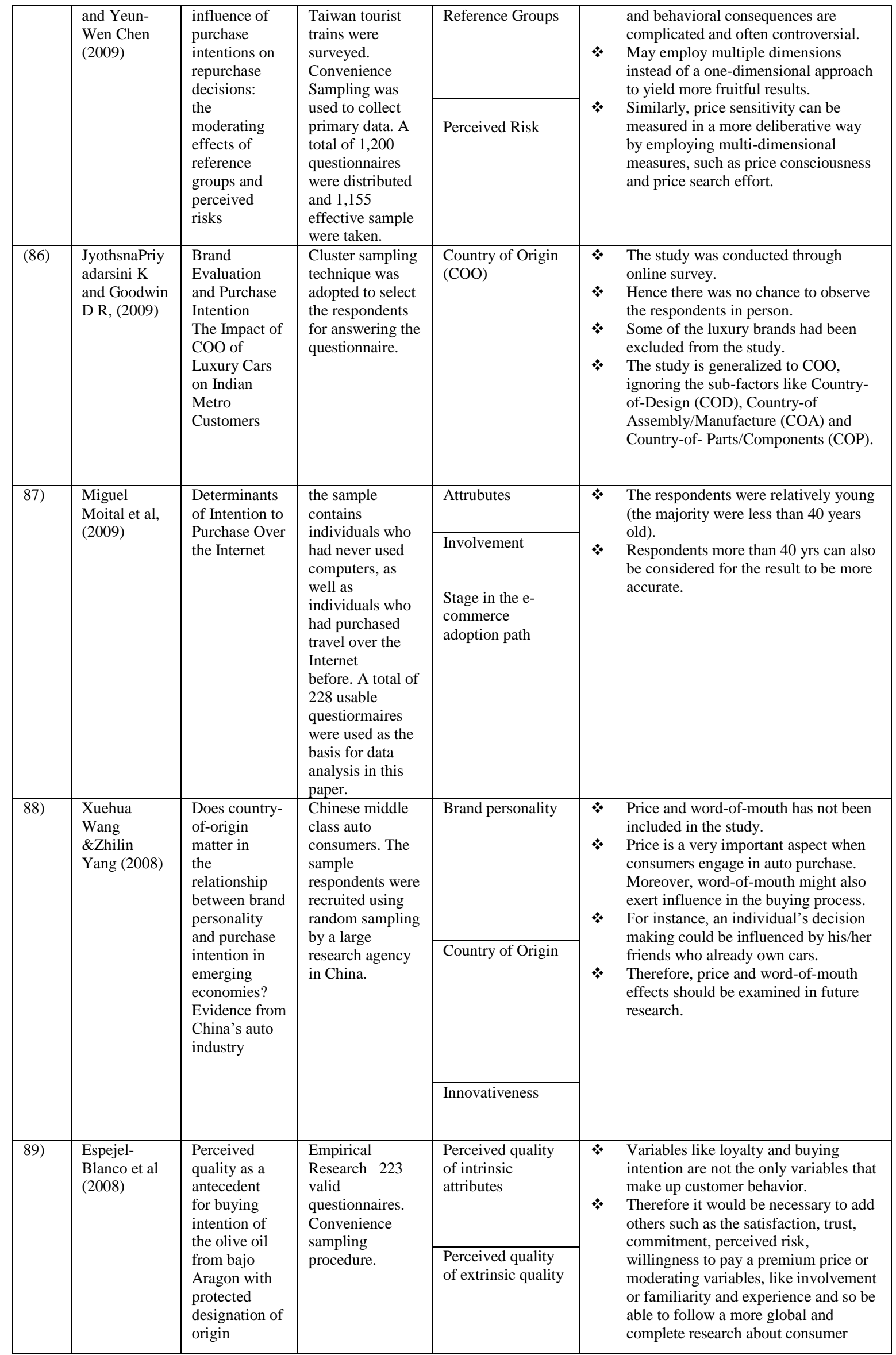




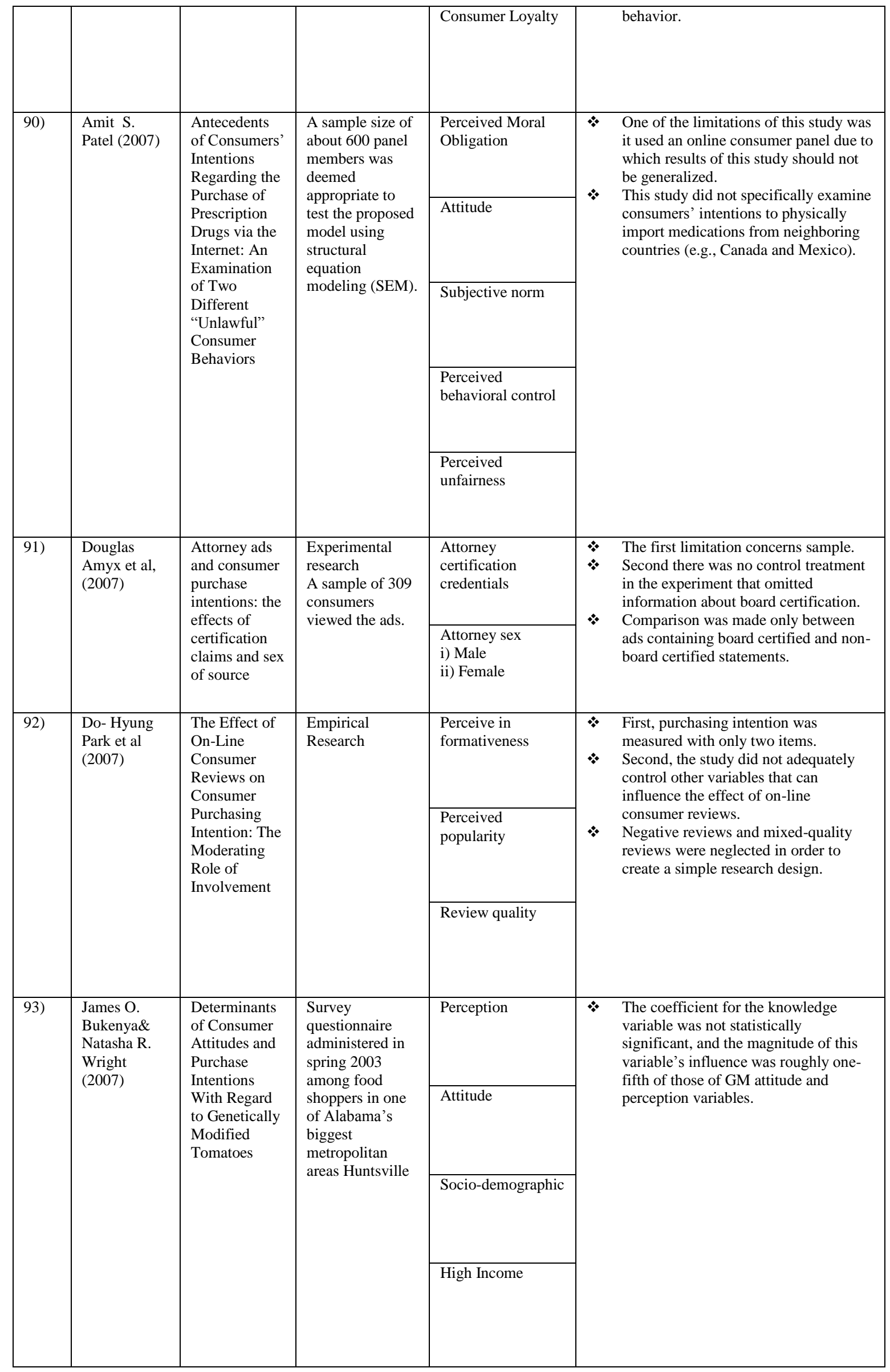




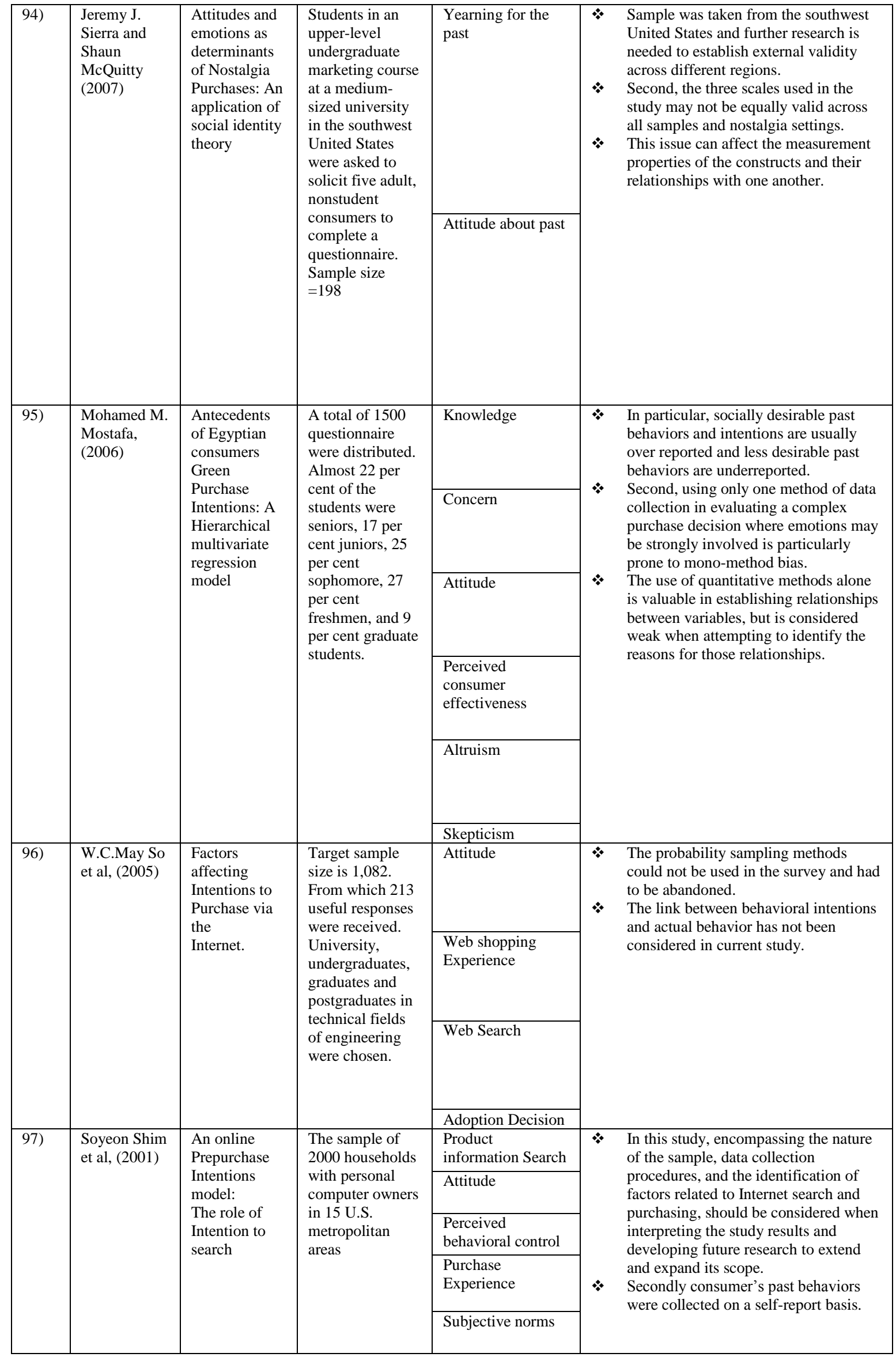




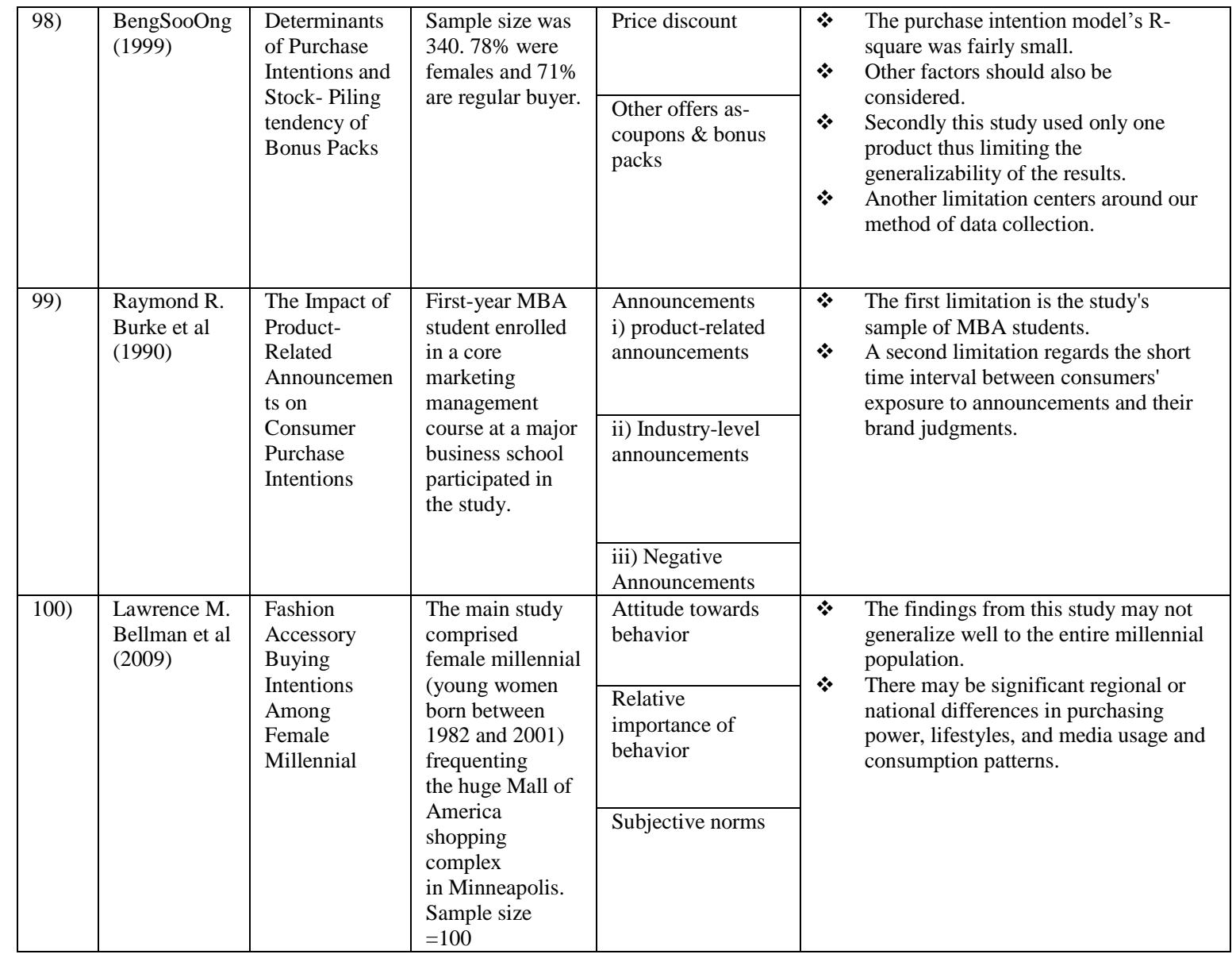

III. . Proposed Research Framework

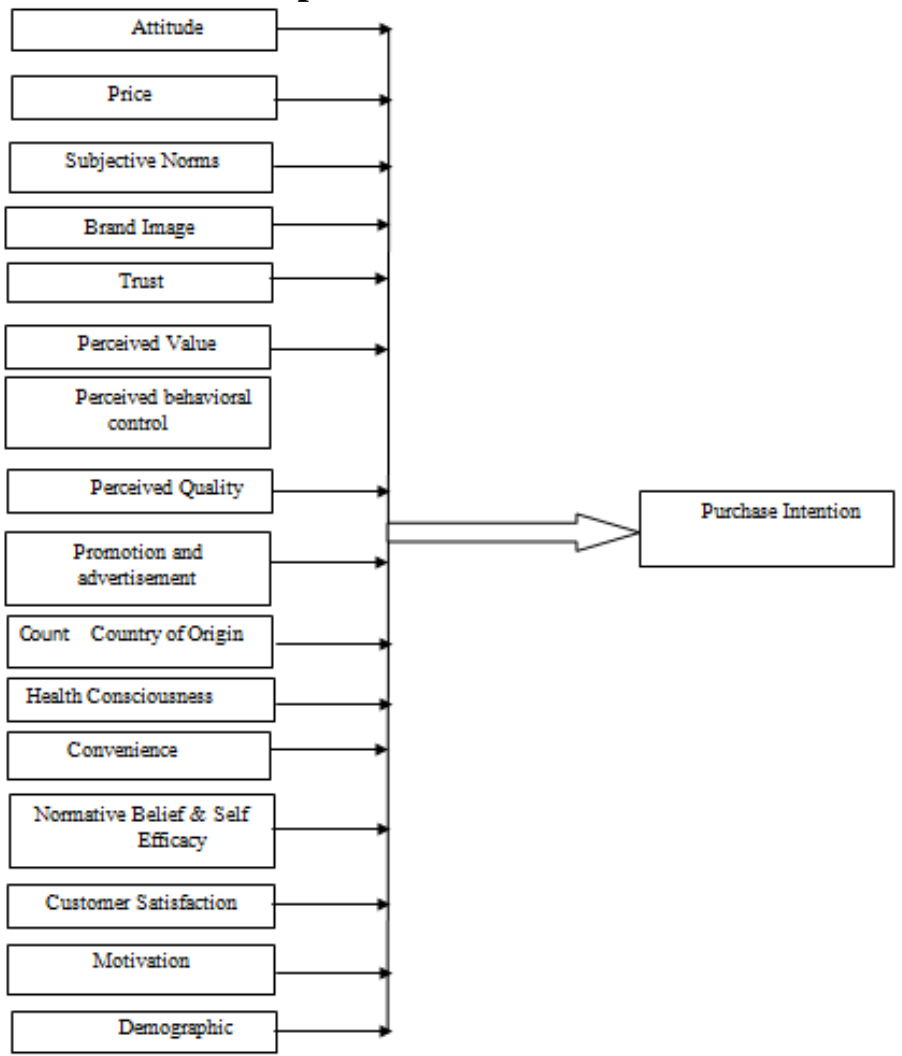

Research Framework 


\section{Conclusion and Future Scope/Limitation}

This paper focuses on the study of various antecedents which directly or indirectly affects the purchase intention. In the present paper exhaustive study has been done on one hundred papers that are published in different renowned journals. Several factors play vital role namely Brand, Price, Promotion \& Advertisement, Convenience, Attitude, Perceived Value, Demographic, Country of Origin, Perceived Quality, trust. Motivation, Normative belief and Self Efficacyetc while considering the purchase intention. Some of the antecedents are common for all the products and are used as antecedents by most of the researchers. Some antecedents differ based on the type of product considered. It has been classified in two categories, namely i) Factors of consensus and ii) factors of non consensus. On the same basis research framework has been framed which is given in section 3.Authors in this paper have focused on the antecedents in general. Further study can be done on finding the antecedents for different products. Product based study will be targeted in near future.

Like others papers it has also some limitations. Although the present findings provide valuable insights several suggestions for future research are made due to the study's limitations. We could have gone through many more research papers which can assist to analyze more antecedents, meaning there by the numbers of research paper studied could be increased. There is scope of improvement in research framework also that can only be done by increasing the numbers of research paper to be studied.

\section{References}

[1]. Aaker, D.A. (1991) Managing Brand Equity. New York: Free Press. pp. 21-26.

[2]. Aaker, D. A (1991) "Managing Brand Equity: Capitalizing on the Value of a Brand Name," New York: The Free Press.

[3]. Ahasanul, H., Ali, K., \&Sabbir, R. (2006). Factors influencing buying behavior of piracy products and its

[4]. impact to Malaysian market. International Review of Business Research Papers, 5(2), 383-401.

[5]. Ajzen, I. (1991). The theory of planned behavior. Organizational Behavior And Human Decision Processes ,vol. 50, pp. 179-211.

[6]. Abedniya, A., and Zaeim, M. N. (2011), "The Impact of Country of Origin and Ethnocentrism as Major Dimensions in Consumer Purchasing Behavior in Fashion Industry", European Journal of Economics, Finance and AdministrativeSciences, No.33, pp. 222232.

[7]. Al-Sulaiti, K and Bakar, M. J. (1998), “Country of Origin effects: a literature review”,Marketing Intelligence and Planning, Vol. 16 No. 13.

[8]. Anderson, P. and He, X. (1998), "Price influence and age segments of Beijing consumers", Journal of Consumer Marketing, Vol. 15 No. 2, pp. 152-69.

[9]. Anderson, E. W., \& Mittal, V. (2000). Strengthening the satisfaction-profit chain. Journal of Service research, 3(2), 107-120.

[10]. Angulo, A.M., Gil, J.M., Tamburo, L. (2003). Food safety and consumers' willingness to pay for labelledbeef in Spain. paper presented at the 83rd EAAE Seminar, Chania, 4-6 September, available at:www.maich/eaae.gr Accessed on 3rd December 2009.

[11]. Bagozzi, R. P Dholakia, U. M.(2002). Mustering motivation to enact decisions: How decision process characteristics influence goal realization Journal of Behavioral Decision Making, 15(3), 167-188.

[12]. BIkely, W.J. and Nes, E. (1982), Country of Origin Effects on Product Evaluations, Journal of International Business Studies, Vol. 1 No. 3, pp 131-141.

[13]. Bullmore, J. 1984. The Brand and It's Image Re-Visited. International Journal of Advertising. pp. 235.

[14]. Brunso, K., Bredahl, L., Grunert, K.G. and Scholderer, J. (2005). "Consumer Perception of the Quality of Beef Resulting from Various Fattening Regimes", Livestock Production Science, Vol. 94, pp. 83-93.

[15]. Bernues, A., Olaizola, A. and Corcoran, K. (2003). "Extrinsic Attributes of Red Meat as Indicators of Quality in Europe: An Application for Market Segmentation", Food Quality and Preference, Vol. 14, pp. 265-276.

[16]. Budd, R.J., \& Spencer, C.P. (1985).Exploring the role of personal normative-beliefs in the theory of reasoned action: the problem of discriminating between alternative path model. Journal of Social Psychology, vol. 15, pp. 299-313.

[17]. Badura, A. (1986). The explanatory and predictive scope of self-efficacy theory. Journal of Social Clinical Psychology, vol. 4, pp. 358-373.

[18]. Bargh, J.A. (2002), "Losing Consciousness: Automatic Influences on Consumer Judgment Behavior and Motivation”, Journal of Consumer Research, 29, 280-285.

[19]. Broekhuizen, T. (2006). Understanding Channel Purchase Intentions: Measuring Online and O\&ine Shopping Value Perceptions. Ridderkirk (Netherlands): $\mathrm{O}=$ setdrukkerijRidderprint B.V.

[20]. Chen, C.H \& Chang, Y.W, (2001), “The Impact of Brand Associations on Brand Equity”, Journal of Management, 18(1), 3-14.

[21]. Chin, W.W., \& Todd, P.A. (1995). On the use, usefulness, and ease of use of structural equation modeling in misresearch: a note of caution. MIS Quarterly, vol. June, pp. 237-245.

[22]. Cronin, J. J., Brady, M. K. \&Hult, G. T. M (2000) “Assessing the Effects of Quality Value and CustomerSatisfaction on Consumer Behavioral Intentions in Service Environments," Journal of Retailing, vol.76(2), p. 193-218.

[23]. Dodds, W. B., \& Monroe, K. B. (1985). The Effect of Brand and Price Information on Subjective Product Evaluation. In H. Elizabeth, \& H. Morris (Eds.), Advances in consumer research. Provo, UT: Association for Consumer Research, pp. 85-90.

[24]. Dodds, W. B., Monroe, K. B. \&Grewal, D (1991) "Effects of Price, Brand, and Store Information on Buyers'Product Evaluation," Journal of Marketing Research, vol. 28, p. 307-319.

[25]. Davis, F.D. (1989). Perceived usefulness, perceived ease of use and user acceptance of information technology. MIS Quarterly, Vol. 13, pp. 319-340.

[26]. Davies. A., Tetterington A.J., Cochrane. C. (1995). Who buy Organic Food? A profile of the purchasers of organic food in Northern Ireland. British Food Journal, Vol. 97 No. 10, pp. 17-23.

[27]. Dichter E. (1962), The World Customer,Harvard Business Review, 40, 1962, p.113-22 [July-August].

[28]. DICK, A. and BASU, K. (1994). "Customer Loyalty: toward an Integrated Conceptual Framework", Journal of the Academy of Marketing Science, Vol. 22, n², pp. 99-113.

[29]. Davis, F.D. (1989). Perceived usefulness, perceived ease of use and user acceptance of information technology. MIS Quarterly, Vol. 13, pp. $319-340$.

[30]. Fotopoulos.C. \&Krystallis.A. (2002) Organic Product Avoidance: Reasons for Rejection and PotentialBuyers' Identification in a Coutrywide Survey. British Food Journal. 104(3/4/5), pp. 233-260. 
[31]. Gefen, D., \& Straub, D. W., (2003). Managing user trust in B2C e-services. E-Service Journal, 2(2), 7- 24.

[32]. Gist, M.E. (1989). The influence of training method on self-efficacy and idea generation among managers. Personality Psychology, Vol. 42, pp.787-805.

[33]. Gupta, S., \& Zeithaml, V. (2006). Customer metrics and their impact on financial performance. Marketing Science, 25(6), 718-739.

[34]. Ha-Brookshire, J. (2012), "Country of origin factors influencing US consumers' perceived price for multinational products", Journal of Consumer Marketing, Vol.29 No.6, pp. 445-454.

[35]. Henson, S. (1996). Consumer willingness to pay for reductions in the risk of food poisoning in the UK. Journal of Agricultural Economics, Vol. 4, pp.403-20.

[36]. Hansen, R. \&Deutscher, T. (1977), “An Empirical Investigation of Attribute Importance in Retail Store Selection”, Journal of Retailing, 53(4), Elsevier, 59-72.

[37]. Huang, J. H., Lee, B. C., \&Hsun Ho, S. (2004). Consumer attitude toward gray market goods. International Marketing Review, 21(6), 598-614

[38]. Keller, K. L (1993) “Conceptualizing, Measuring, and Managing Customer-Based Brand Equity,” Journal of Marketing, vol. 57(1), p. 1-22.

[39]. Keller, K. L (1998) Strategic Brand Management, New York: Prentice Hall.

[40]. Kotler, P., \& Keller, K. L. (2009). Marketing management. (13th Pearson International Ed.). Englewood Cliffs: Prentice Hall.

[41]. Kotler, P (2000) Marketing Management, 10th ed., New Jersey: Prentice-Hall.

[42]. Keller, K. L. (2003). Strategic Brand Management: Building, Measuring, and Managing Brand Equity. (2nd ed.). Upper Saddle River, New Jersey 07458, USA: Prentice Hall/Pearson Education Inc.

[43]. Lafferty, B. A. \& Goldsmith, R. E. (1999), “Corporate Credibility’s Role in Consumers' Attitudes and Purchase Intentions When a High Versus A Low Credibility Endorser Is Used in The Ad", Journal of Business Research, 44, Elsevier, 109-116.

[44]. LaBarbera, P. A., \& Mazursky, D. (1983). A Longitudinal Assessment of Consumer Satisfaction, Dissatisfaction: the Dynamic Aspect of Cognitive Process. Journal of Marketing Research, 20, 393-404.

[45]. Landry, J.T. (1998), “Are Chinese consumers coming of age?”,Harvard Business Review, Vol. 76 No. 3, pp. 17-18.

[46]. Lang, J. Q., \& Crown, E. M. (1993). Country- of- origin effect in apparel choices: A conjoint analysis. Journal of Consumer Studies \& Home Economics, 17(1), 87-98.

[47]. Mayer, R. C., Davis, J. H., \&Schoorman, F. D., (1995). An integrative model of organizational trust. Academy of Management Review, 20, $709-734$.

[48]. Mourali, M. et al (2005), "Country Image Structure and its Influence on Consumer Evaluations of Foreign Products,” International Marketing Review, 22 (1), 96-115.

[49]. Nabil, J., \&Imed, Z. (2010). The impact of label perception on the consumer's purchase intention: an application on food products. IBIMA Business Review, 2, 2-14

[50]. Nebenzahl I.D., Jaffe' E.D., Lampert S.I., (1997), "Towards A Theory of Country Image Effect on Product Evaluation", Management International Review, 37, pp. 27-49.

[51]. Olson, J. and Jacoby, J. (1972). "Cue Utilization in the Quality Perception Process". En Venkatesan M., Proceedings of the Third Annual Conference of the Association for Consumer Research. Chicago: Association for Consumer Research, pp. 167-179.

[52]. Olsen, S.O. (2002). "The Comparative Evaluation and the Relationship between Quality, Satisfaction, and Repurchase Loyalty", Journal of the Academy of Marketing Science, Vol. 30, n³, pp. 240-249.

[53]. Ophuis, P. A. O., \& Van Trijp, H. C. (1995). Perceived quality: A market driven and consumer oriented approach. Food quality and Preference, 6(3), 177-183.

[54]. Padel, S., Foster, C. (2005). Exploring the gap between attitudes and behaviour: Understanding why consumers buy or do not buy organic food. British Food Journal, 107 (8), pp. 606 - 625. Planet Retail, (2007), "7-Eleven Became the Largest Chain Store World Wide".

[55]. Park, H., Rabolt, N. and Jeon, K. (2008), "Purchasing global luxury brands among young Korean consumers", Journal of Fashion Marketing and Management, Vol. 12 No. 2, 2008 pp. 244-259.

[56]. Reichheld, F. F., Markey Jr, R. G., \&Hopton, C. (2000). The loyalty effect-the relationship between loyalty and profits. European Business Journal, 12(3), 134

[57]. Reinartz, W., \& Kumar, V. I. S. W. A. N. A. T. H. A. N. (2002). The mismanagement of customer loyalty. Harvard business review, 80(7), 86-95

[58]. Richardson, Paul S., Alan S. Dick, and Arun K. Jain. "Extrinsic and intrinsic cue effects on perceptions of store brand quality." The Journal of Marketing(1994): 28-36.

[59]. Safiek, M. (2009b). Malaysian Chinese consumers: Their ethnic attitudes and shopping orientations.International Journal of Business and Management, 4(11), 53-62.

[60]. Schifferstein, H.N.J. and Oude Ophuis, P.A.M. (1998). Health-related determinants of organic foods consumption in The Netherlands. Food Quality and Preference, Vol. 9 No. 3, pp. 119-33.

[61]. Supanvanij, J., and Amine, L. S. (2000), "Consumer Perception of Country-of-Origin Effect and Brand Effect", Latin AmericanBusiness Review, Vol.1 No.4, pp. 47-60. Abedniya, A., and Zaeim, M. N. (2011), "The Impact of Country of Origin and Ethnocentrism as Major Dimensions in Consumer Purchasing Behavior in Fashion Industry", European Journal of Economics, Finance and AdministrativeSciences, No.33, pp. 222-232.

[62]. Schmitt, B. (1997), "Who is the Chinese consumer? Segmentation in the People's Republic of China", European Management Journal, Vol. 13 No. 2, pp. 191-4.

[63]. Simonson, I. (2005). In defense of consciousness: The role of conscious and unconscious inputs in consumer choice.

[64]. Steemcamp, J.B. (1997). Dynamics in Consumer Behaviour with Respect to Agricultural and Food Products. En Wierenga, B., Tilburg, van A., Grunert, K., Steemkamp, J.B. y Wedel, M. (Eds.), Agricultural Marketing and Consumer Behaviour in a Changing World. Dordrecht: Kluwer Academic Publishers. pp. 143-188

[65]. Szybillo, G. J., \& Jacoby, J. (1974). Intrinsic versus extrinsic cues as determinants of perceived product quality. Journal of Applied Psychology,59(1), 74

[66]. Tan, M., \& Teo, T. S. (2000). Factors influencing the adoption of Internet banking. Journal of the AIS, 1(1es), 5.

[67]. Usunier et al, (2009), "Ranking with ordered weighted pairwise classification", Proceedings of the $26^{\text {th }}$ International Conference on Machine Learning.

[68]. Wind, J., \&Rangaswamy, A. (2001). Customerization: The next revolution in mass customization. Journal of interactive marketing, 15(1), 13-32

[69]. White, R. (2003). Best Practice. Using Brand Image. Admap (January 435): pp. 13-14 
[70]. Woodruff, R. B., Schumann, D. W. \&Gardial, S. F. (1993). 'Understanding Value and Satisfaction From Customer's Point of View,' Survey of Business, 28pg 33-40

[71]. Zeithaml, V. A (1988) "Consumer Perceptions of Price, Quality, and Value: A Means-End Model and Synthesis of Evidence," Journal of Marketing, vol. 52 (July), p. 2-22.

[72]. Zeithaml et al, (1985), "Problems and Strategies in Services Marketing", Journal of Marketing, 49, 33-46. 